(C) 2020 by the Arizona Board of Regents on behalf of the University of Arizona. This is an Open Access article, distributed under the terms of the Creative Commons Attribution licence (http://creativecommons. org/licenses/by/4.0/), which permits unrestricted re-use, distribution, and reproduction in any medium, provided the original work is properly cited.

\title{
CHRONOLOGY OF THE BURIAL ACTIVITY OF THE LAST HUNTER-GATHERERS IN THE SOUTHWESTERN IBERIAN PENINSULA, PORTUGAL
}

\section{R Peyroteo-Stjerna*(i)}

Human Evolution, Evolutionary Biology Centre, Department of Organismal Biology, Uppsala University, Norbyvägen 18C, SE-752 36 Uppsala, Sweden

UNIARQ, Centro de Arqueologia, University of Lisbon, Portugal

\begin{abstract}
For most of human history, funerary burial has been unusual. Archaeology shows a shift in funerary practices in postglacial hunter-gatherers, in parts of Europe during the Late Mesolithic. This is documented by the burial grounds in the Tagus and Sado valleys in the southwestern Iberian Peninsula, Portugal, where ca. 376 burials were excavated. This study presents a chronology for the burial activity in these sites and contextualizes the start and end activity phases within regional environmental changes and cultural developments. The dataset consists of $76{ }^{14} \mathrm{C}$ dates on human bone (19 new, 57 published) including new dates from contexts in Portugal outside these valleys. Bayesian chronological models were defined in OxCal, and protein carbon contributions of marine foods were estimated by the Bayesian mixing model FRUITS. The results indicate a broader timeframe for the Late Mesolithic in Portugal, than previously suggested, starting during a period of significant environmental changes, ca. 8500-8300 cal BP, and ending ca. $7000 \mathrm{cal}$ BP. The burial activity decreased during the establishment of Neolithic farmers in southwestern Iberia from ca. 7450 cal BP, however, these burial grounds continued to be used by Mesolithic hunter-gatherers, showing that diverse social structures and worldviews coexisted for several generations.
\end{abstract}

KEYWORDS: burial practice, chronology, hunter-gatherers, Mesolithic, shell midden.

\section{INTRODUCTION}

Death rituals involving the burial of the deceased were unusual until the Late Mesolithic (Pettitt 2011). The Mesolithic shell middens of the Tagus and Sado valleys in Portugal are remarkable because of the large number of human bodies buried in these sites. These are some of the largest and earliest burial grounds known, arranged and maintained by the last populations of hunter-gatherers in southwestern Europe (Jackes and Lubell 2012; Umbelino and Cunha 2012; Peyroteo Stjerna 2016a). The development of open-air burial grounds contrasts with earlier practices in the region; burial was practiced in the Iberian Peninsula, however, it was not a common treatment (Peyroteo Stjerna 2016b).

The chronology of these burial grounds was established on typological analysis (Breuil and Zbyszewski 1947; Roche 1972; Araújo 1997) and on several radiocarbon $\left({ }^{14} \mathrm{C}\right)$ dates (Roche 1957; Delibrias and Roche 1965; Arnaud 1989; Lubell et al. 1994; Larsson 1996; Arnaud 2000; Cunha and Cardoso 2001; Cunha and Umbelino 2001; Cunha et al. 2003; Cunha and Cardoso 2003; Roksandic 2006; Meiklejohn et al. 2009; Detry and Cardoso 2010; Bicho et al. 2013; Jackes et al. 2014; López-Dóriga et al. 2016; Peyroteo Stjerna 2016a). These are generally framed within the Late Mesolithic chronology in Portugal, ca. 8300 7200 cal BP (Araújo 2015), or more conservatively ca. 8150-7550 cal BP (Carvalho 2009).

This study examines the chronology of the burial activity of the last hunter-gatherers in southwestern Iberia, Portugal, and contextualizes the start and end activity phases within regional environmental changes and cultural developments. The broad chronology has been established but there are several outstanding issues that this paper aims to address:

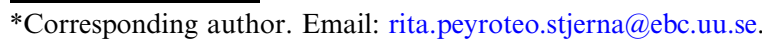


1. The nature and context of the ${ }^{14} \mathrm{C}$ dates has not been systematically assessed in terms of the human activity they are supposed to date. Samples used in this study come from buried human bone only, and the reliability of the isotopic measurements is assessed.

2. Stable isotopes of carbon $\left({ }^{13} \mathrm{C}\right)$ and nitrogen $\left({ }^{15} \mathrm{C}\right)$ indicate the consumption of foods from terrestrial and marine reservoirs (Lubell et al. 1994; Fontanals-Coll et al. 2014; Guiry et al. 2015; Peyroteo Stjerna 2016a), which may influence the calibration of ${ }^{14} \mathrm{C}$ measurements and their chronological interpretation (Stuiver et al. 1986). This study applies a new approach to estimate the protein carbon contribution to diet with the Bayesian mixing model FRUITS (Fernandes et al. 2014), and uses these measurements to calibrate the ${ }^{14} \mathrm{C}$ dates with the Bayesian chronological models in OxCal (Bronk Ramsey 2009).

3. The burial activity of the last hunter-gatherers in Portugal clusters in the Tagus and Sado valley, and the evidence for human remains outside these regions is scarce and largely undated (Peyroteo Stjerna 2016b). This paper investigates human remains in Late Mesolithic contexts outside these river valleys and provides new ${ }^{14} \mathrm{C}$ dates.

4. Hunter-gatherer and farmer relations at the onset of the Neolithic in Portugal, ca. 74507250 cal BP (Carvalho 2010; Martins et al. 2015) are poorly understood. A recent study suggested that one of the Tagus burial grounds was used simultaneously by Mesolithic and Neolithic people (Bicho et al. 2017). This paper tests this hypothesis from a multisite perspective by examining all human remains dated at the end boundaries of the burial activity.

The chronological analysis is based on a dataset of $76{ }^{14} \mathrm{C}$ dates on human bone (19 new, 57 published), excavated in Late Mesolithic contexts in Portugal. While the focus on the human burials allows the establishment of chronologies based on strong indicators of mortuary activity, other uses of the sites were not considered in this study.

\section{ARCHAEOLOGICAL BACKGROUND}

Most human remains dating to the Late Mesolithic in Portugal are in open-air shell midden sites in the valleys of two major southern rivers, the Tagus and the Sado (Peyroteo Stjerna 2016b). The Tagus middens are located on the lower valley, ca. $80 \mathrm{~km}$ northeast from the river mouth in Lisbon, on the banks of three tributaries to the Tagus River: Fonte da Moça, Muge, and Magos. The sites of the Sado valley are located ca. $120 \mathrm{~km}$ south of Muge and ca. $80 \mathrm{~km}$ east from the river mouth (Figure 1). From the 13 middens identified in the Tagus valley, nine have human remains with a minimum number of individuals (MNI) of 263 (Paço 1938; Santos et al. 1990; Cunha and Cardoso 2001; Cunha and Cardoso 2003; Roksandic 2006; Jackes and Meiklejohn 2008; Meiklejohn et al. 2009; Bicho et al. 2013). Similarly, in the Sado valley, there are 11 known middens, six of which with human burials to a total of ca. 113 individuals (Cunha and Umbelino 1997; Diniz et al. 2014).

Late Mesolithic human remains found outside these river valleys are rare. One tooth dating to the Late Mesolithic was excavated in an open-air site in southern Portugal (Carvalho et al. 2008). Skeletal remains were also found in a shell midden located in the Mira valley on the coast of Alentejo (Arnaud 1988; Lubell et al. 2004), and new ${ }^{14} \mathrm{C}$ data confirm the Late Mesolithic chronology of the remains. Lastly, one skeleton excavated in the rock shelter Abrigo Grande das Bocas was interpreted as possibly Mesolithic based on the analysis of the original field notes (Bicho 1995). ${ }^{14} \mathrm{C}$ measurements obtained for this study (Beta447678) date the death of this individual to 133-330 cal CE (Table S1.1). 

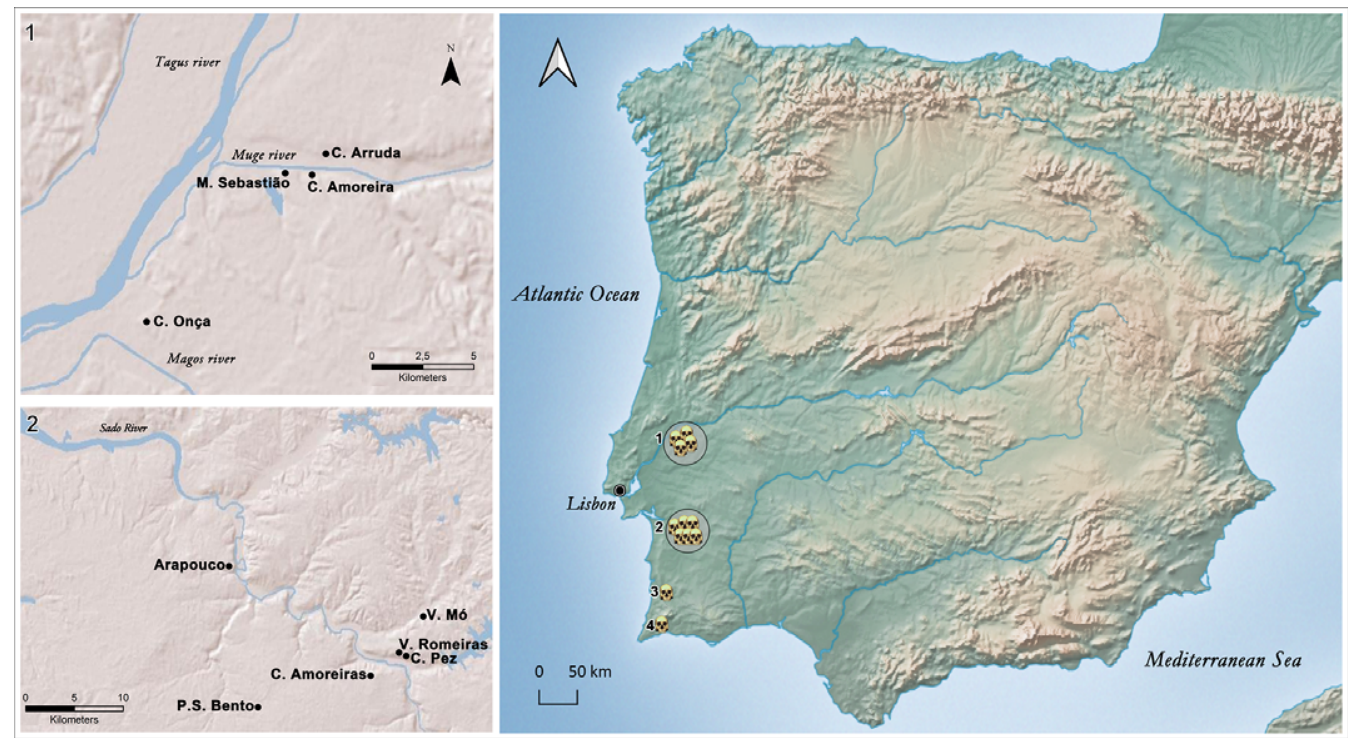

Figure 1 Iberian Peninsula and the location of the sites with ${ }^{14} \mathrm{C}$ dated human remains discussed in this paper. 1) Tagus valley: Moita do Sebastião, Cabeço da Amoreira, Cabeço da Arruda, Cova da Onça; 2) Sado valley: Arapouco, Poças de S. Bento, Cabeço da Amoreira, Vale de Romeiras, Cabeço do Pez, Várzea da Mó; 3) Mira valley: Fiais; 4) Vale Boi.
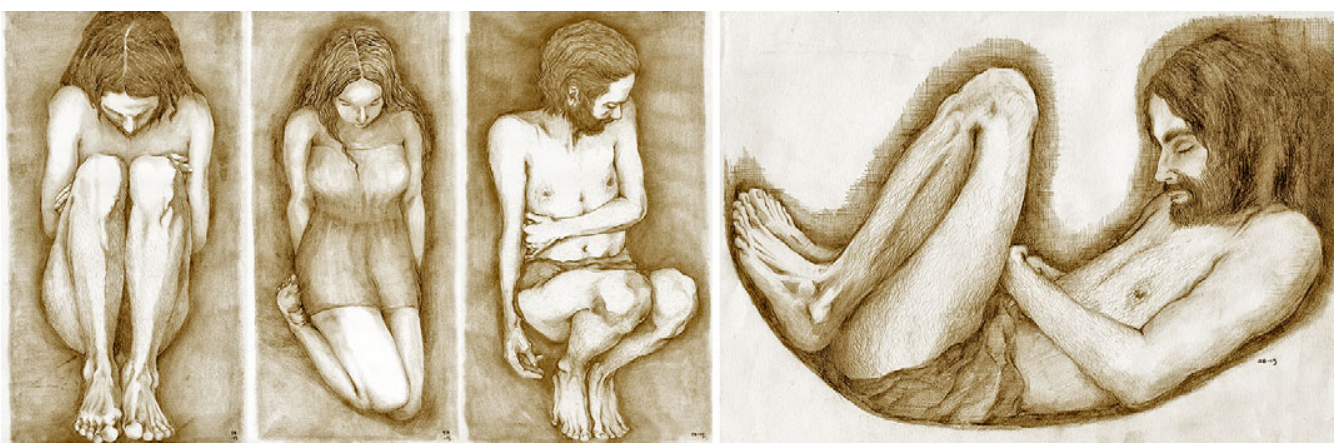

Figure 2 Human burials in the shell middens of the Tagus and Sado valleys as reconstructed in Peyroteo Stjerna (2016a). Drawings by Susanna Berglund.

At the Tagus and Sado valleys, the burial of the deceased was a common way of handling the cadaver. Mortuary practices in both valleys were based on common principles indicating a shared mindset on the treatment of the dead (Peyroteo Stjerna 2016a). There were slight variations, but these did not affect the overall pattern of the treatment of the dead. The cadavers were typically placed in individual graves, soon after death, while retaining their anatomical integrity. The bodies were normally laid on the back, with the upper limbs arranged close to the body, and with the lower limbs in flexion at various degrees, with the feet often placed towards the buttocks (Figure 2). Typically, the cadavers lay underground and undisturbed in their graves. In some instances the bones of a previous burial were 
partially removed to accommodate the burial of a new cadaver, indicating the continued preference of certain areas for the burial of the dead within a larger area of the site (Roche 1972; Peyroteo Stjerna 2016a). The relation between these burial clusters and the remaining areas of the sites remains an open question.

In rare cases, burial analyses confirm the multiple nature of primary deposits containing the remains of two individuals (Roksandic and Jackes 2014; Peyroteo Stjerna 2016a). Recently, the context CAM-01-01 at Cabeço da Amoreira was referred to as a multiple burial, possibly in successive episodes, corresponding to changes in Mesolithic funerary patterns, in line with Neolithic practices (Bicho et al. 2013; Bicho et al. 2017). This interpretation is not supported by archaeological data. While CAM-01-01 contained the skeletal remains of one main individual and bone fragments of at least three others, this observation alone is not evidence of a multiple burial. The bones were distributed over an area of $2 \times 2 \mathrm{~m}$ and excavated between $0.2-0.6 \mathrm{~m}$ from the surface of the shell midden. The material was heavily disturbed by recent activities, but it was possible to reconstruct the burial position of the main individual (Roksandic 2006). The scattering and fragmentation of the bones, as well as the lack of key observations (Duday 2009) such as the identification of a common burial context, or the common arrangement of the remains does not allow the determination of CAM-01-01 as a multiple burial of Neolithic tradition.

These middens are also rich in faunal and botanical remains providing evidence for the consumption in situ of a varied range of food resources, terrestrial, estuarine and marine (Lentacker 1986; Lentacker 1994; Detry 2007; Marques-Gabriel 2015; Rowley-Conwy 2015; López-Dóriga et al. 2016). There is no evidence for domesticated plants or animals, except for the domestic dog (Detry and Cardoso 2010; López-Dóriga et al. 2016). Stone tool production is also well documented for all stages of the chaîne opératoire (Araújo 1997; Marchand 2001; Nukushina 2012; Diniz and Nukushina 2014; Cascalheira et al. 2015). The few fragments of pottery found in some areas of the sites show evidence for occasional Neolithic activity (Ferreira 1974; Bicho et al. 2011; Diniz and Cubas 2015).

In southwestern Iberia, the Late Mesolithic settlement was clustered in the innermost areas of large estuaries, in contrast with the scattered pattern known for the Early Mesolithic (Araújo 2015). Explanations for this reconfiguration (Zilhão 2003; Bicho et al. 2010) are based on paleoenvironmental evidence. Here, the rapid sea level rise during 12,000-7000 cal BP resulted in the drowning of the Tagus and Sado valleys creating inland sheltered seas and tidal environments several kilometers upstream (van der Schriek et al. 2007; Vis et al. 2008; Costa et al. 2019). Data from Muge show the rapid establishment of inner estuarine environments ca. 8050 cal BP (van der Schriek et al. 2007), although the tidal mudflat and saltmarsh conditions were settling in earlier (Vis et al. 2008). Research in the Sado valley indicates a similar pattern (Costa et al. 2019), and preliminary data suggest that estuarine conditions existed as early as 8500 BP (A. Costa, pers. comm.). These new ecosystems were particularly attractive not only because of their natural resources, but also because of their sheltered inland position with easy access to the interior and to the Atlantic coast through connected waterways. As the sea level rise declined, the river systems prevailed, and the estuaries began to contract. In Muge this occurred between ca. 7450-5750 cal BP and an open landscape was established around ca. $6950 \mathrm{cal}$ BP, although the same rich and diverse ecological systems remained until at least ca. 5750 cal BP (van der Schriek et al. 2007). In the Sado valley, the estuarine environment and the transitional marine-fluvial habitats were still productive until ca. 3300 cal BP, at least at Arapouco (Costa et al. 2019). 
Table 1 Summary of the dataset: archaeological sites, minimum number of individuals (MNI), number of ${ }^{14} \mathrm{C}$ dates and number of dated individuals.

\begin{tabular}{llccc}
\hline Region, tributary river & Archaeological site & MNI & No. dates & No. inds. \\
\hline Tagus valley, Muge & Moita do Sebastião & 85 & 19 & 19 \\
& Cabeço da Amoreira & 29 & 16 & 15 \\
& Cabeço da Arruda & 110 & 18 & 16 \\
Tagus valley, Magos & Cova da Onça & 32 & 4 & 4 \\
Sado valley & Arapouco & 32 to 36 & 2 & 1 \\
& Poças de S. Bento & 16 & 1 & 1 \\
& Cabeço das Amoreiras & 6 & 3 & 3 \\
& Vale de Romeiras & 26 & 2 & 2 \\
Mira valley & Cabeço do Pez & 32 to 36 & 8 & 6 \\
Algarve & Várzea da Mó & 1 & 1 & 1 \\
Total & Fiais & 1 to 2 & 1 & 1 \\
\hline
\end{tabular}

\section{MATERIALS}

The analysis was based on ${ }^{14} \mathrm{C}$ dates on buried human bone exclusively. Dates on other material are available, such as on charcoal and shells, but with few exceptions (Bicho et al. 2013; Jackes et al. 2015; López-Dóriga et al. 2016) the context is unclear and the relationship with the burials is unknown.

A total of 76 sets of measurements of ${ }^{14} \mathrm{C}$ and stable isotopes of ${ }^{13} \mathrm{C}$ and ${ }^{15} \mathrm{~N}$ were selected for analysis, corresponding to 70 individuals. This material was excavated since the 19 th century from the shell middens in the Tagus valley $(n=4)$ : Moita do Sebastião, Cabeço da Amoreira, Cabeço da Arruda, Cova da Onça; in the Sado valley $(n=6)$ : Arapouco, Poças de S. Bento, Cabeço das Amoreiras, Vale de Romeiras, Cabeço do Pez, Várzea da Mó; in the Mira valley $(\mathrm{n}=1)$ : Fiais; and in the open-air site Vale Boi (Table 1).

Five sites in the Tagus valley with human remains but without direct ${ }^{14} \mathrm{C}$ dates on human bone were not included in this study: Fonte da Moça 1 and 2 (fragments of bones) (Santos et al. 1990), Fonte do Padre Pedro (MNI =2-3), Flor da Beira (MNI=4-5) (Meiklejohn et al. 2009), Cabeço dos Morros (MNI = 1) (Paço 1938).

Moita do Sebastião is located on a low terrace, 20 m.a.s.1., on the left bank of Muge (Roche 1972). It has excellent access and visibility towards the river and towards Cabeço da Arruda on the opposite margin. The neighboring site of Cabeço da Amoreira is ca. $700 \mathrm{~m}$ east. It was excavated in the 19th century (Ribeiro 1884; Paula e Oliveira 1888), and in 1952-1954 after the destruction of the top layers of the shell midden which were estimated to be at ca. $2.5 \mathrm{~m}$ from the bottom river-terrace sands (Roche and Ferreira 1967). Despite the depth of the midden, it has been suggested that possibly all skeletons were excavated from the lower layers (Jackes and Alvim 2006).

Cabeço da Amoreira is located 15 m.a.s.l. on the left bank of Muge, on the opposite side to Cabeço da Arruda, ca. $700 \mathrm{~m}$ east of Moita do Sebastião (Roche 1965). The site was excavated in 1884-1885 (Paula e Oliveira 1888), 1930-1931, 1933 (Cardoso and Rolão 
2000), 1961-1964 (Roche 1965), 2001-2003 (Roksandic 2006), and 2008-present (Bicho et al. 2013). The shell midden has a depth of ca. $3.5 \mathrm{~m}$ in the central area and human remains were excavated from the top layer down to the bottom sandy layer on the base of the midden (Roksandic and Jackes 2014).

Cabeço da Arruda is located on the right bank of Muge, 8 m.a.s.l., on the edge of the floodplain. The site has excellent visibility towards the river and towards Moita and Amoreira on the opposite margin. It was excavated in the 19th century (Ribeiro 1884; Paula e Oliveira 1888), 1933 and 1937 (Cardoso and Rolão 2000), 1964-1965 (Roche 1967), and in 2000 (Roksandic 2006). Arruda is the largest shell midden in Portugal reaching ca. $5 \mathrm{~m}$ in depth in the central area (Roche 1967), with human remains excavated from various depths of the midden (Peyroteo Stjerna 2016a).

Cova da Onça was the first shell midden discovered in Portugal, in April 1863 (Ribeiro 1884). The site is located 2 to $8 \mathrm{~m}$.a.s.1. on the right bank of Magos near another midden named Cabeço dos Ossos. Both sites are destroyed. There is no documentation known for this site and the bones are stored in disarticulated state and mixed in containers without identification or stratigraphic information (Cunha and Cardoso 2003; Meiklejohn et al. 2009; Peyroteo Stjerna 2016a).

Arapouco is the westernmost shell midden in the Sado valley. The site is located on the left margin of the river at 47 m.a.s.l., and has excellent visibility over the valley (Diniz and Arias 2012). It was excavated in 1961-1962, but there is no information about the location of the burials in the midden. According to Dario de Sousa who did the site drawings, which are missing from the site archives, all burials were in the bottom sandy layer beneath the layers with shells (Peyroteo Stjerna 2016a).

Poças de S. Bento stands on a plateau ca. $3 \mathrm{~km}$ from the Sado River at 85 m.a.s.1. with no visibility towards the valley, unlike most sites (Diniz and Arias 2012). The site was excavated in 1960, 1964, 1986-1988, and 2010-2017 (Arnaud 1989; Larsson 1996; Arias et al. 2015). All burials were identified in the basal sandy layers ca. $1.6-1.8 \mathrm{~m}$ deep, at the bottom of the shell midden (Peyroteo Stjerna 2016a).

Cabeço das Amoreiras is located on the left margin of the Sado River at 52 m.a.s.l. (Diniz and Arias 2012). The site was excavated in 1958, 1985-1986, and 2014-2016 (Arnaud 1989; Diniz et al. 2015). The human remains were excavated from the bottom sandy layer in a small area of ca. $25 \mathrm{~m}^{2}$, at depths ranging from 1.2 to $1.5 \mathrm{~m}$ from the top of the shell midden (Peyroteo Stjerna 2016a).

Vale de Romeiras is located on the eastern side of the Sado valley, on the right margin of the river at 55 m.a.s.1. It has excellent visibility over the valley, Cabeço das Amoreiras on the opposite margin, and Cabeço do Pez on the neighboring hilltop (Diniz and Arias 2012). The site was excavated in 1959-1960, and most burials were found lying on the bottom sand or soft bedrock at depths ranging from 0.1 to $0.84 \mathrm{~m}$ due to the significant erosion of the top layers of the midden (Peyroteo Stjerna 2016a).

Cabeço do Pez is one of the largest sites in the Sado valley. It is located on the eastern part of the valley, on the right margin of the river at 52 m.a.s.l., on a hilltop next to Vale de Romeiras, with good visibility over the river (Diniz and Arias 2012). It was the first shell midden discovered in the valley (Barradas 1936), but was excavated only 20 years later in 1956 and 1958-1959 
(Peyroteo Stjerna 2016a), as well as in 1983 and 2010 (Arnaud 1989; Arias et al. 2015). Documentation is limited but most skeletons seem to have been excavated from the sand layer and on top of the bedrock beneath the layers with shells. The two individuals identified in 1959 were excavated from a middle layer with shells $0.18-0.8 \mathrm{~m}$ deep (Peyroteo Stjerna 2016a).

Várzea da Mó is located on the eastern side of the Sado valley on the right margin of the river, 8-25 m.a.s.1., but the precise location of the site is unknown (Diniz and Arias 2012). It was excavated in 1959 and only one skeleton was identified. The human remains were excavated on the bottom of the shell midden at a depth of ca. $0.65 \mathrm{~m}$ (Peyroteo Stjerna 2016a).

Fiais is located $10 \mathrm{~km}$ from the modern coast, on a high terrace of the Mira River at 100 m.a.s.1., and was excavated in 1986-1988 (Arnaud 1988; Lubell et al. 2004). Fragments of human bones of possibly several individuals were excavated in 1986-1987, found scattered and mixed with faunal remains. In 1988, the remains of one individual were found clustered but disarticulated in one area of the site (Arnaud 1988). These remains have not been analyzed and the MNI and nature of the deposits are unknown.

Vale Boi is an open-air site located in the southern coast of Portugal, 60 m.a.s.l. The site was active during the Upper Paleolithic and Neolithic. One loose human tooth was excavated in 2004 and ${ }^{14} \mathrm{C}$ dated to the Late Mesolithic. The nature of this isolated find is unknown, and according to the excavators, if there is a Mesolithic occupation in this site, it has not yet been found (Carvalho et al. 2008).

Samples collected for this study $(\mathrm{n}=19)$ and respective permits were obtained from the Geological Museum/MG (Lisbon, Portugal) in the case of Cova da Onça and Cabeço da Amoreira (1962); from the Museum of Natural History and Science, University of Porto/ MHNC-UP (Porto, Portugal) in the case of Cabeço da Arruda, Cabeço da Amoreira (1930s) and Moita do Sebastião; and from the National Museum of Archaeology/MNA (Lisbon, Portugal) in the case of Arapouco, Cabeço do Pez, and Fiais.

\section{METHODS}

\section{Estimate of the Marine Carbon Contribution towards Bone Collagen}

The concentration of ${ }^{14} \mathrm{C}$ in the sea, rivers, and lakes is generally lower than that in the contemporary atmosphere due to a slower mixing rate between the chemical elements in the atmosphere and the water surface. Because of this relative lower concentration in ${ }^{14} \mathrm{C}$, the organisms grown in water reservoirs will variably present relatively older ${ }^{14} \mathrm{C}$ ages, than those from coeval terrestrial environments. Thus, the foods consumed from different primary reservoirs, terrestrial or from the water systems, will determine the ${ }^{14} \mathrm{C}$ incorporated in each archaeological sample (Stuiver et al. 1986). This is particularly important when calibrating ${ }^{14} \mathrm{C}$ measurements from humans that may derive their carbon from foods of terrestrial and/or marine origin.

Protein carbon from marine and terrestrial sources in the specimen's bone collagen are estimated using FRUITS 3.0 (Food Reconstruction Using Transferred Signals, Fernandes et al. 2014). FRUITS introduced the Bayesian mixing model approach to diet reconstruction studies, and it is used to provide more accurate estimates of food intake using simple or complex models, depending on the nature of the data and on the 
archaeological question. To correct chronologies obtained from ${ }^{14} \mathrm{C}$ dating of human bone collagen that potentially have a reservoir effect, a simple concentration-independent and non-routed model can be defined by using the measured $\delta^{13} \mathrm{C}$ value of each sample (Fernandes 2015). This is a powerful method not only because it provides an estimate of the protein carbon from marine and terrestrial foods for each consumer, but also the associated uncertainties, which can be included in the chronological calibration. The output of the model is presented on Table 2 ( $\%$ marine). See Supplementary Material (S2) for specific details on model parameters and assumptions.

\section{Calibration and Modeling}

The dataset excludes individuals with ${ }^{14} \mathrm{C}$ measurements published without independently measured isotope-ratio mass spectrometry (IRMS) isotopic values (Table S1.2) because only IRMS-based values can be reliably used for isotopic-based environmental analysis such as reservoir corrections (Millard 2014; Taylor and Bar-Yosef 2014). The parameter collagen yield $(\% \mathrm{C}, \% \mathrm{~N})$ was not always provided by the laboratories, and for this reason, the atomic carbon and nitrogen ratios $(\mathrm{C}: \mathrm{N})$, and $\delta^{13} \mathrm{C}$ and $\delta^{15} \mathrm{~N}$ were used for quality checks. The acceptance ranges of the atomic ratio of carbon and nitrogen $(\mathrm{C}: \mathrm{N})$ are within the 2.9-3.6 range (DeNiro 1985; van Klinken 1999), although C:N ratios between 3.4-3.6 may indicate some contamination (Ambrose 1993). See Supplementary Material (S3) for specific details on ${ }^{14} \mathrm{C}$ laboratory protocols.

All chronological models are defined by a Bayesian approach to the analysis and interpretation of ${ }^{14} \mathrm{C}$ measurements in archaeological contexts (Bayliss et al. 2007; Bayliss 2009). In the case of sites with one ${ }^{14} \mathrm{C}$ date an independent event calibration is used.

The standardized likelihoods (the dates) consist of ${ }^{14} \mathrm{C}$ dates on human bone collagen. The proportion of protein carbon intake from marine sources is estimated by FRUITS 3.0 (Fernandes et al. 2014), using the Atlantic Iberia endpoint values of $-12.0 \%$ and $-20.8 \%$ o for marine $(100 \%)$ and terrestrial $(100 \%)$ diets, respectively (Cubas et al. 2018). Samples are calibrated using IntCal13 and Marine13 curves (Reimer et al. 2013), and the regional reservoir offset ca. $7000 \mathrm{BP}: \Delta \mathrm{R}_{\text {Tagus }}=140 \pm 40{ }^{14} \mathrm{C} \quad \mathrm{yr} ; \Delta \mathrm{R}_{\text {Sado }}=-100 \pm 155{ }^{14} \mathrm{C}$ yr; $\Delta \mathrm{R}_{\text {West Coast }}=95 \pm 15{ }^{14} \mathrm{C}$ yr; $\Delta \mathrm{R}_{\text {Algarve }}=69 \pm 17{ }^{14} \mathrm{C}$ yr (Martins et al. 2008; Martins and Monge Soares 2013; Peyroteo Stjerna 2016a).

The prior beliefs (the archaeology) are limited to the surviving documentation. Stratigraphic relations of the dated material are limited, and the Bayesian models are primarily defined by simply incorporating the information that the dates derived from a coherent archaeological activity (i.e., burial activity). Despite the limitations, the application of the method allows the estimate of posterior densities of the ${ }^{14} \mathrm{C}$ measurements, which are more precise than single date estimates (Bayliss 2009).

The models are outlined in OxCal 4.3 (Bronk Ramsey 2009) which provides the posterior beliefs for each model and event. For this study, the most suitable kind of model is the site-based model. Site-based models are defined as phase models framed by two undated events, i.e. boundaries, for the start and end of activity. The introduction of boundaries in a model is a way to make the events relate statistically to each other by accounting for the scatter of dates due to measurement uncertainty. This approach is particularly useful when we do not 
have explicit archaeological data indicating a clear order of a group of elements (Bronk Ramsey 1995), such as in the case of historical collections with scarce documentation. This is a reliable approach because each sample corresponds to a burial event which is part of the burial activity at the site.

Two statistical criteria produced by $\mathrm{OxCal}$ are used for reliability and consistency testing: the index of agreement (A) and convergence (C) (Bronk Ramsey 1995). A is high ( $\geq 60 \%$ ) when the posterior distribution is situated in a high probability region of the prior distribution. If $\mathrm{A}$ is low $(<60 \%)$ the result is regarded problematic, or it may indicate the presence of a statistical outlier. The overall index of agreement (Aoverall) provides a measure of the consistency between the prior information and the ${ }^{14} \mathrm{C}$ results. Aoverall is typically ca. $100 \%$ with a threshold value of $60 \%$, and models which produce values lower than this should be re-examined (Bronk Ramsey 1995; Bayliss et al. 2007). The index of convergence indicates how quickly the sampler algorithm can produce a representative and stable solution to the model. In practice, a model is unstable when $\mathrm{C}$ is poor $(<95 \%)$ and the results should not be used (Bronk Ramsey 1995).

Calendar ages are reported as "cal BP" (Before Present, where Present is 1950 CE). All calibrated ranges are given at $95 \%$ probability. The calibrated ranges quoted in italics derive from mathematical modeling and are posterior density estimates. In each plot, the large square brackets and the OxCal keywords define the overall model. For each of the dates two distributions have been plotted, one in outline which is the result produced by the scientific evidence alone, and a solid one which is based on the chronological model used. Calibrated ranges of $95 \%$ and $68 \%$ probability are plotted by the lower and higher square brackets, respectively.

\section{RESULTS: SITE-BASED CHRONOLOGY OF THE BURIAL ACTIVITY}

\section{Moita do Sebastião}

Two chronological models were built on $19{ }^{14} \mathrm{C}$ dates, one of which is new, on skeletons from all excavation areas (Table 2). One published measurement (Beta-127449) was excluded from the models because its $\delta^{13} \mathrm{C}$ value was obtained by AMS (C. Umbelino, pers. comm.) (Table S1.2).

Chronological model 1 assumes one general phase of burial activity and does not impose a relative order to the dated events. The model shows good overall agreement and the agreement index for each dated event is high, except for the sample Ua-46264 (9, 19521954) which is in poor agreement but in good convergence (Figure 3). This sample is the earliest dated burial in the site and its greater age suggests an earlier event relatively older than the group of events in the considered phase. Its low agreement and the visual observation of the plot suggests the possibility of more than one archaeological phase of burial deposition. As a working hypothesis, and based on the visual observation of the plot, a second model is proposed, by explicitly defining three main periods of burial activity as three phases, with boundaries defined for each phase (Figure 4). Model 2 shows good overall agreement, and the agreement index for each dated event is high, indicating that the ${ }^{14} \mathrm{C}$ dates are in accordance with the model. Sample Ua-46264 which is in poor agreement in model $1(\mathrm{~A}=38 \%, 8292-7996 \mathrm{cal} \mathrm{BP})$ is in good agreement in model 2 $(\mathrm{A}=62 \%, 8344-8017 \mathrm{cal} \mathrm{BP})$. Nevertheless, model 2 should be considered with caution. 


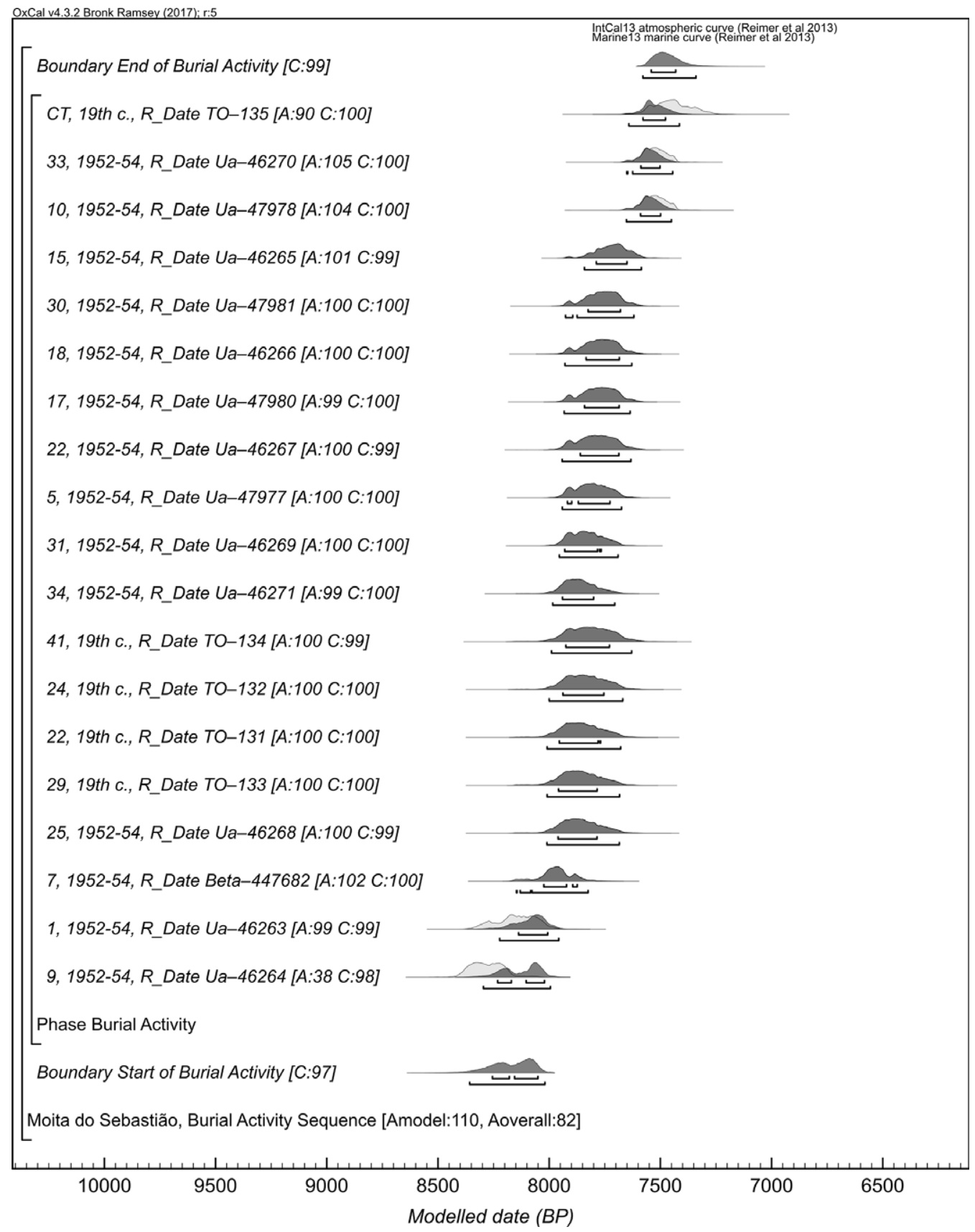

Figure 3 Chronological model 1 for the burial activity at Moita do Sebastião, Muge, Tagus valley.

The archaeological data is insufficient, and we know only that the burials were excavated from the basal sand layer, at the bottom of the shell midden. This is not to suggest that the burial activity could not have happened in distinct phases, but to caution against the manipulation of the data, which, without a strong archaeological basis, can be significantly misleading. 


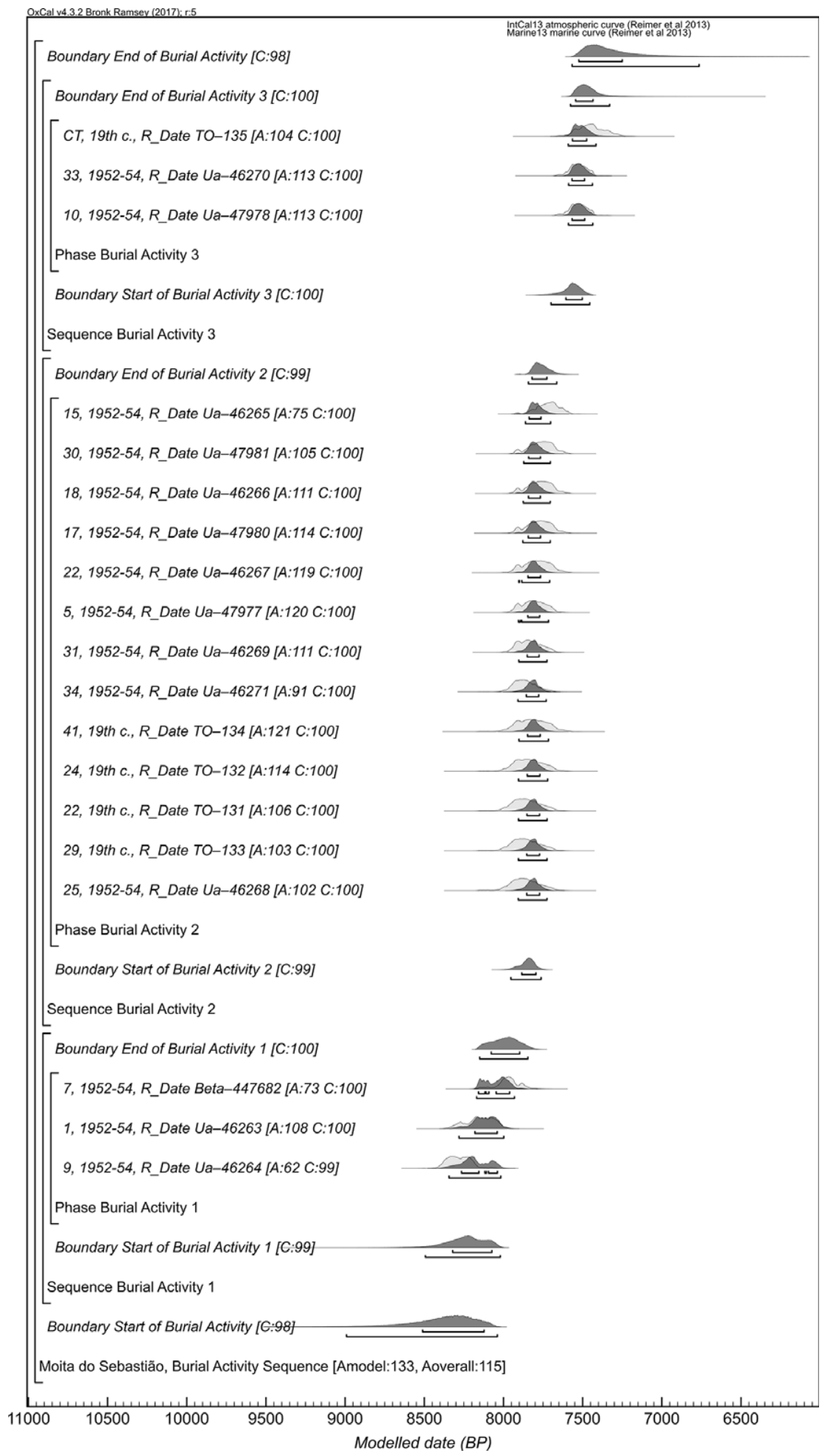

Figure 4 Chronological model 2 for the burial activity at Moita do Sebastião, Muge, Tagus valley. This model is a working hypothesis because current archaeological data does not securely allow the construction of a robust second model. 
Overall, the available ${ }^{14} \mathrm{C}$ measurements can be considered representative of the burial assemblage. The chronological sequence suggests that the burial activity clustered in three chief moments, possibly discontinuously, with relatively short hiatuses between them without significant burial activity. At Moita do Sebastião the burial activity was frequent and continuous between ca. 8000-7600 cal BP (mod. 1) or 7900-7700 (mod. 2), supporting earlier suggestions of a main group of burials clustering at ca. 7800 cal BP (Jackes and Lubell 2012). Burials from all excavated areas fall into this time span, indicating that when the burial practice was more frequent, the extent of the burial area was as large as the total burial area known. The earliest mortuary activity is estimated to have been between ca. 8300-7900 cal BP, when the local estuarine environment was expanding, as indicated by burials 9, 1, and 7. The burial activity seems to end ca. 7650-7450 cal BP, while the favorable estuarine ecosystem was still predominant, as illustrated by the dates of individuals 10,33 , and CT.

\section{Cabeço da Amoreira}

Two chronological models were built on $16{ }^{14} \mathrm{C}$ dates, eight of which are new, on skeletons from all excavation areas (Table 2). One published measurement for individual CAM-00-01 (TO-10218) was excluded from the models because it was replaced by a reanalysis (TO-11819-R) (Meiklejohn et al. 2009; Jackes and Lubell 2015) (Table S1.2). Two ${ }^{14} \mathrm{C}$ measurements available for CAM-00-01 (TO-11819-R and UOC-913) were calibrated using the OxCal function $R_{-}$Combine and the average between the marine carbon estimates.

Chronological model 1 assumes one general phase of burial activity and does not impose a relative order to the dated events. The model shows satisfactory overall agreement and the agreement index for each dated event is high, except for the samples CAM-00-01 (TO-11819-R, UOC-913) and CAM-01-01 (Wk-26796), which are in poor agreement but in good convergence (Figure 5). These are the oldest and youngest dates available and may indicate an earlier event relatively older than the group of events in the considered phase, as well as a more recent event.

Chronological model 2 tests the previously proposed 3-burial phase chronology for Cabeço da Amoreira (Bicho et al. 2013), which was based on the stratigraphic sequence as documented in recent excavations, and on AMS measurements on human bone $(n=7)$, shells $(n=28)$ and charcoal $(\mathrm{n}=1)$ :

- Phase 1, bottom layer: burials 2011.1 (Wk-32143) and CAM-00-01 (TO-11819-R);

- $\quad$ Phase 2, upper layers: burials 2011.2 (Wk-32142) and 7, 1933 (Beta-127450);

- Phase 3, upper layers: burial context CAM-01-01 (Wk-26796, TO-10225, and TO-10218, note that this latter measurement has been rejected, see above).

Model 2 assumes 3-phases by explicitly defining three main periods of burial activity with boundaries defined for each phase as in Bicho et al. 2013. The burials newly dated $(n=8)$ are added to each phase by simply considering their calibrated date ranges, regardless of their known depth in the midden. At Cabeço da Amoreira, burial depth and chronology are not entirely correlated as indicated by burial 1 (1930) in the bottom sand and burial 6 (1933) at $1.3 \mathrm{~m}$ from the top, which cluster in time with burials excavated in the upper layers (Figure 5, Table 2). Model 2 shows good overall agreement, and the agreement index for each dated event is $\geq 60 \%$. Samples CAM-00-01 (TO-11819-R, UOC-913) and 


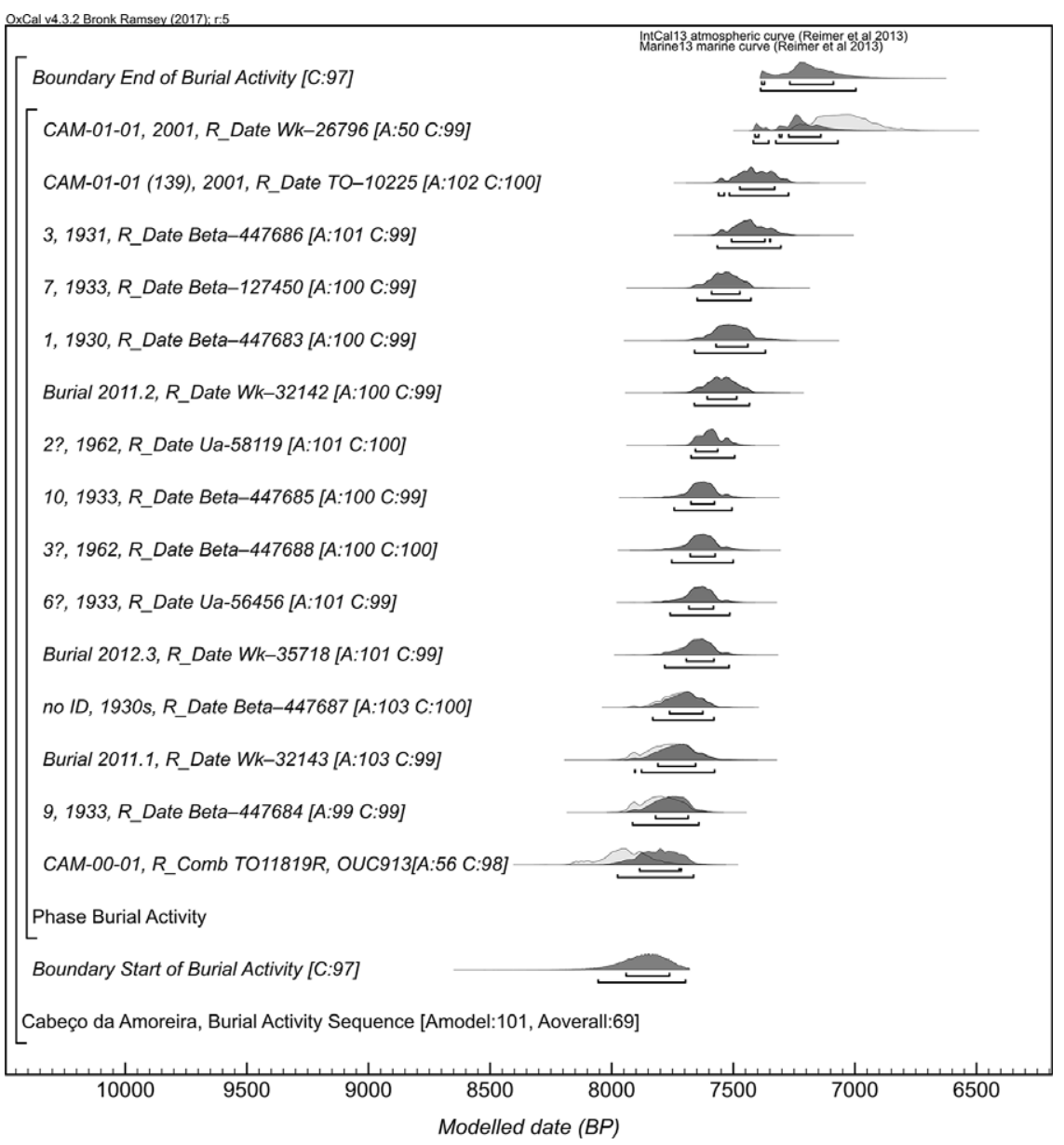

Figure 5 Chronological model 1 for the burial activity at Cabeço da Amoreira, Muge, Tagus valley.

CAM-01-01 (Wk-26796) which are in poor agreement in model 1 are in good agreement in model 2.

Both models 1 and 2 show that burial activity was more frequent and continuous than previously suggested (Peyroteo Stjerna 2016a). However, data from the new excavations seems to indicate that the burial activity clustered in three chief moments (mod. 2), possibly discontinuously, with relatively short hiatuses without significant burial activity. While model 2 may be well resolved in the light of the new documentation for the site, it is unclear how it fits with previous archaeological data. The models are comparable at the start and end of the burial activity at the site, but without further examination of the earlier excavations the hiatuses estimated by model 2 should be considered with caution (Figure 6).

The earliest burial activity is estimated to have been ca. $8000-7600 \mathrm{cal} \mathrm{BP}(\bmod .1)$ or ca. 8000 7700 cal BP (mod. 2, phase 1), when the favorable local estuarine environment was well established, as indicated by the burials of individuals CAM-00-01, 9 (1933), and 2011.1. 


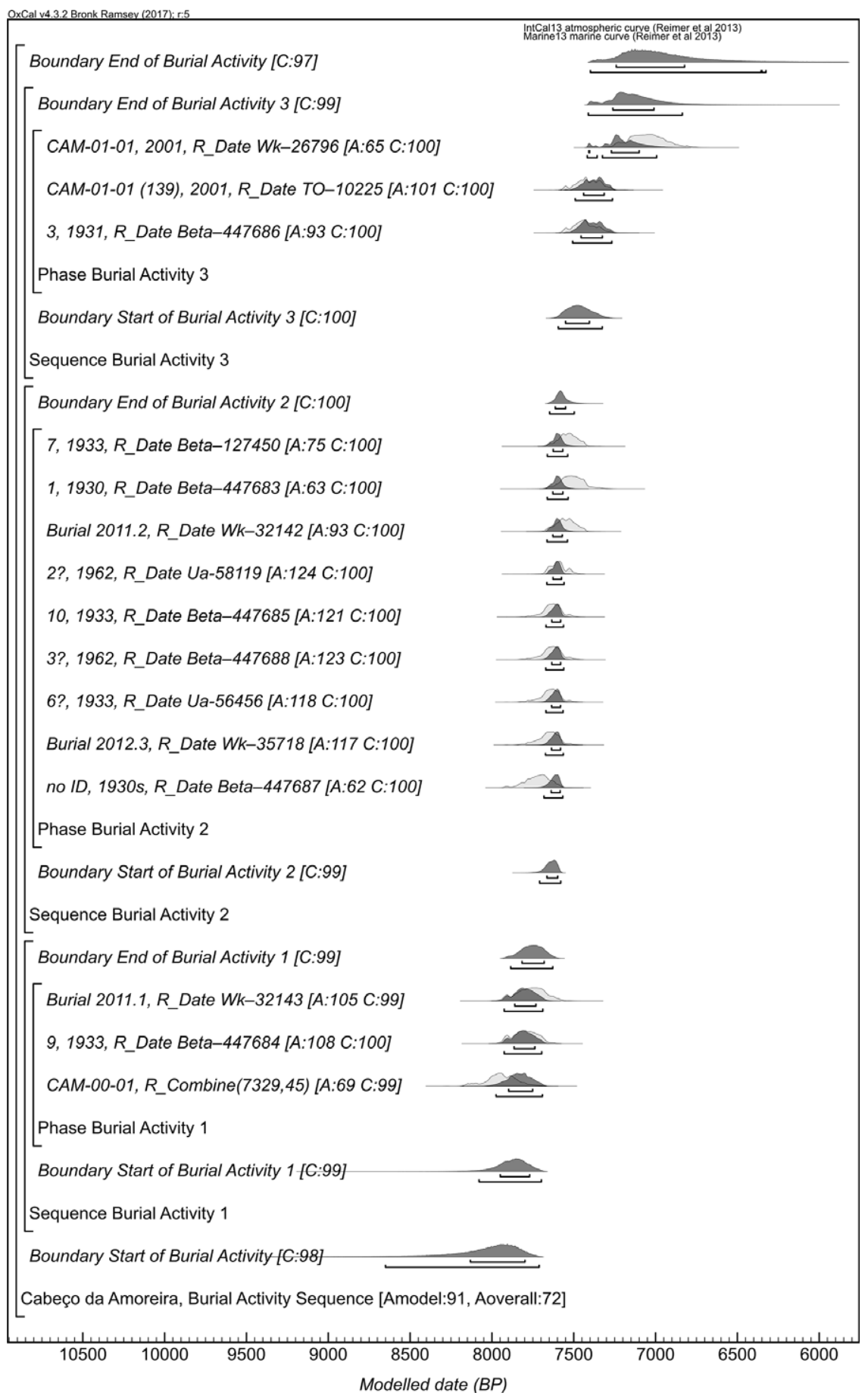

Figure 6 Chronological model 2 for the burial activity at Cabeço da Amoreira, Muge, Tagus valley. This 3-phase model estimates hiatuses between phases 1 and 2 of $0-235$ years (95\% probability) or 28-169 years (68\% probability), and between phases 2 and 3 of $0-239$ years (95\% probability) or $0-142$ years $(68 \%$ probability). Without further archaeological examination of the earlier excavations these hiatuses should be considered with caution. 
Most burials cluster between ca. 7800-7400 cal BP in model 1, but in model 2, the main burial activity concentrates between ca. $7700-7550$ cal BP (mod. 2, phase 2) suggesting high frequency of burial practice at the site. Burials from the upper, middle and bottom layers fall into this time span. The burial activity decreases and seems to end between ca. 7560-7070 cal BP (mod. 1), or ca. 7500-7000 cal BP (mod. 2, phase 3), as indicated by burial 3 (1931), and the individuals in context CAM-01-01. Both models show that the end of the burial activity is coeval with the gradual contraction of estuarine habitats, ca. 7450-5750 cal BP, and with the earliest Neolithic activity in Portugal, ca. 7450-7250 cal BP.

\section{Cabeço da Arruda}

The chronological model was built on $18{ }^{14} \mathrm{C}$ dates, three of which are new, on 16 skeletons excavated from all areas (Table 2). Two published measurements on individuals CA-00-01 (Wk-26795) and CA-00-02 (Wk-26794) were excluded from the model because were measured on dental enamel (Table S1.2). Despite improving methods, dating and calibrating measurements on enamel is problematic (Hedges et al. 1995; Hopkins et al. 2016). Fortunately, both skeletons were also collagen dated (TO-10217 and TO-10216). Two ${ }^{14} \mathrm{C}$ measurements available for skeleton 6 (Beta-127451 and AA-101343) were calibrated using the OxCal function $R_{-}$Combine and the IRMS-based $\delta^{13} \mathrm{C}$ value (AA-101343). Likewise, the two ${ }^{14} \mathrm{C}$ measurements for individual III (Beta-447681 and TO-360) were calibrated using $R \_$Combine and the average between the marine carbon estimates.

The model assumes one general phase of burial activity and does not impose a relative order to the dated events. It shows good overall agreement, and agreement index for each dated event is high, except for skeleton $\mathrm{N}$ (TO-356) which is in poor agreement but in good convergence (Figure 7). This individual is the most recent burial known in the site and its younger age may suggest a later event relatively more recent than the group of events in the considered phase.

A second chronological model could be proposed by defining the main phases of burial activity in relation to the documented depth of each burial. Nevertheless, the posterior density estimates in model 1 show that depth and antiquity of the burial are not always correlated. This is the case for CA-00-02 (TO-10216) found in the base of the midden. This burial in the bottom sandy layer, presents a relatively more recent ${ }^{14} \mathrm{C}$ date than burial 6 (Beta127451, AA-101343) which was found $0.8 \mathrm{~m}$ from the base of the midden, as well as more recent than individual 3 (UA-46273) at $1.2 \mathrm{~m}$ from the bottom. Other dated burials, however, seem to follow a vertical chronology, with individual CA-00-01 (TO-10217) at $2 \mathrm{~m}$ from the bottom presenting one of the most recent dates known at the site.

This is a large site with many human burials in a complex stratigraphy. Nevertheless, ${ }^{14} \mathrm{C}$ data indicates that the different burial areas excavated in the 19th century, 1930s, and 1960s were synchronic, and can be analyzed as one series considered representative of the assemblage.

The earliest burial activity at Arruda is estimated to have been between ca. 8150-7850 cal BP, while the estuarine environment was established in the region, as indicated by the ${ }^{14} \mathrm{C}$ dates for individual 6 (Beta-127451, AA-101343). Despite doubts expressed about the early date of this burial (Jackes and Meiklejohn 2004; Jackes and Lubell 2012) the new ${ }^{14} \mathrm{C}$ date on skeleton B (Ua-56457) strengthens the case for the antiquity of these burials. This earlier activity is followed by the main period of burial, where most ${ }^{14} \mathrm{C}$ dates cluster, indicating that burial 


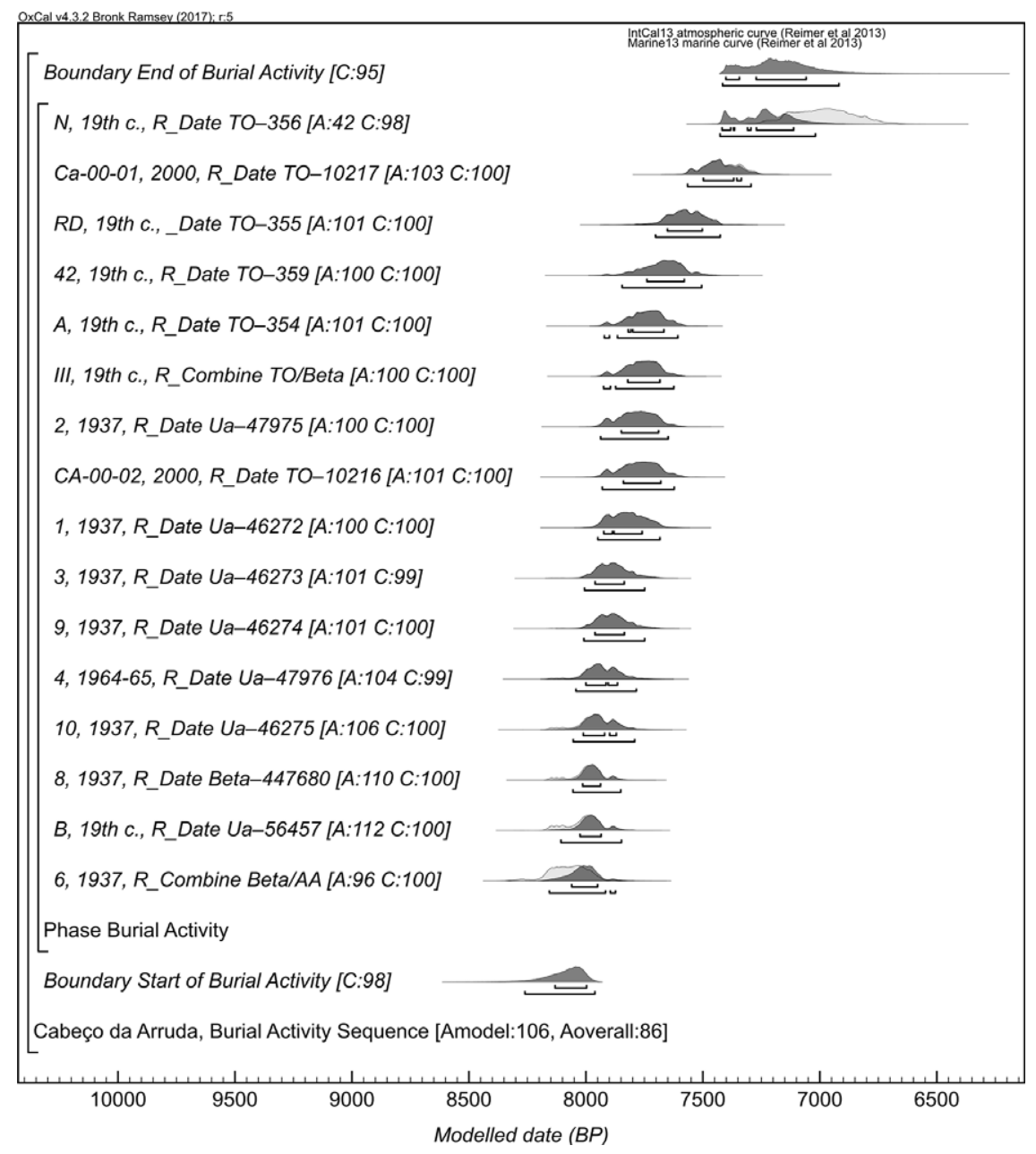

Figure 7 Chronological model for the burial activity at Cabeço da Arruda, Muge, Tagus valley.

practice was more frequent between ca. 8000-7500 cal BP. Burials excavated from all areas fall into this time span.

The only date securely attributed to the upper layers of the shell midden corresponds to the later episodes of burial activity at Arruda (TO-10217, 7566-7294 cal BP) which is good agreement with the remaining ${ }^{14} \mathrm{C}$ measurements. Individual $\mathrm{N}$ (TO-356, 7427-7019 cal BP) is the latest burial known at the site. It presents a more recent date and is in poor agreement with the remaining dates available, suggesting an episode of later burial activity. Its exact location and depth are unknown, although the enveloping sediment corresponds to the characteristic matrix of the upper layers (Jackes and Lubell 2012). More dates from the upper layers could clarify this relatively later burial activity, but the only material securely identified from the upper layers was excavated in 1965 and has been mixed with the skeletons excavated in 1964 from the bottom of the midden (Peyroteo Stjerna 2016a). The end of the activity estimated to ca. $7400-7000$ cal BP is coeval with Early Neolithic activity in Portugal. 


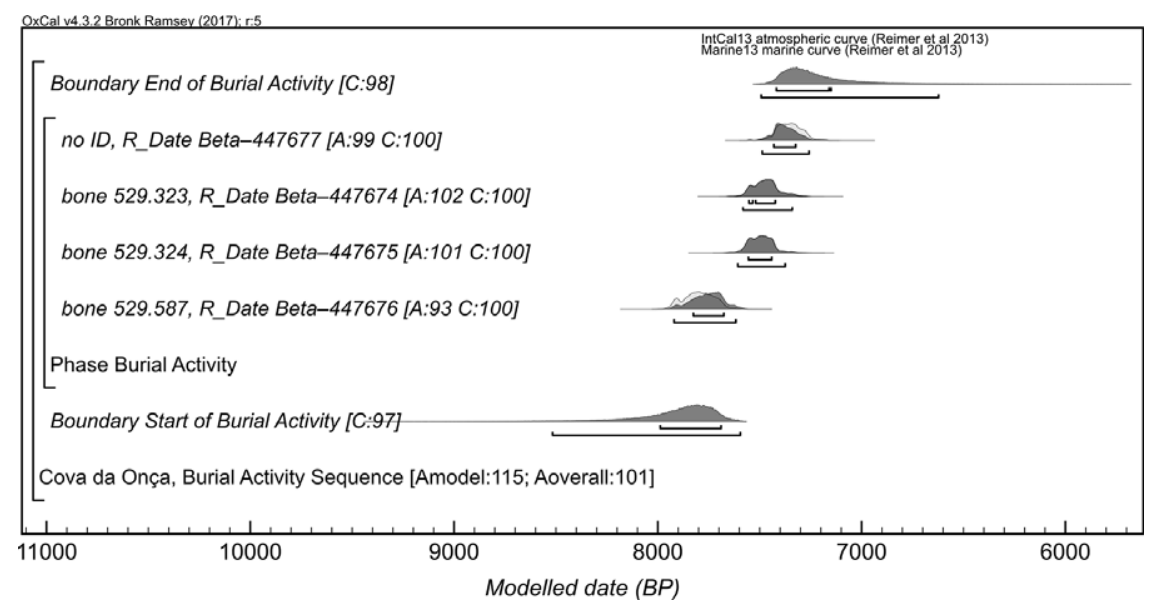

Figure 8 Chronological model for the burial activity at Cova da Onça, Magos, Tagus valley.

\section{Cova da Onça}

The chronological model was built on four new ${ }^{14} \mathrm{C}$ dates (Figure 8, Table 2). One published measurement (Beta-127448) was excluded from the model because its $\delta^{13} \mathrm{C}$ value was obtained by AMS (C. Umbelino, pers. comm.) (Table S1.2).

Burial activity at Cova da Onça seems to be continuous, possibly with one short hiatus between the earliest and main burial activity, which should be tested with further data. Nevertheless, the current model shows good overall agreement and estimates the main activity to have been between ca. 7600-7350 cal BP, with an earlier moment at 7920-7617 cal BP, when the inner estuarine conditions were highly favorable. The later burial activity at the site, estimated at $7488-7258 \mathrm{cal} \mathrm{BP}$, is coeval with the earliest Neolithic phases in Portugal. More dates are necessary to refine this chronology; however, the new data securely confirms the Late Mesolithic chronology of these burials.

\section{Arapouco}

Only skeleton $2 \mathrm{~A}$ provided ${ }^{14} \mathrm{C}$ measurements within the accepted quality ranges (Sac-1560 and Beta-447689), despite multiple attempts (Cunha and Umbelino 2001; Peyroteo Stjerna 2016a). The ${ }^{14} \mathrm{C}$ dates were calibrated using the OxCal function $R_{-}$Combine and the IRMS-based $\delta^{13} \mathrm{C}$ value (Beta-447689). These measurements do not allow the construction of a chronological model for the burial activity at Arapouco but date the death of individual 2A to have been between 8158-7971 cal BP (Table 2). This is a large site with high density of human burials, and despite the poor collagen preservation further ${ }^{14} \mathrm{C}$ measurements should be tried in the future.

\section{Poças de S. Bento}

Two individuals buried at Poças de $\mathrm{S}$. Bento have been ${ }^{14} \mathrm{C}$ measured. One measurement is from the skull excavated in 1986 (Ua-425) which reliability is uncertain because the isotopic values are not available (Table S1.2). The other measurement dates burial 14 excavated in 2013 in the area where all human remains have been found (Diniz et al. 2014; 


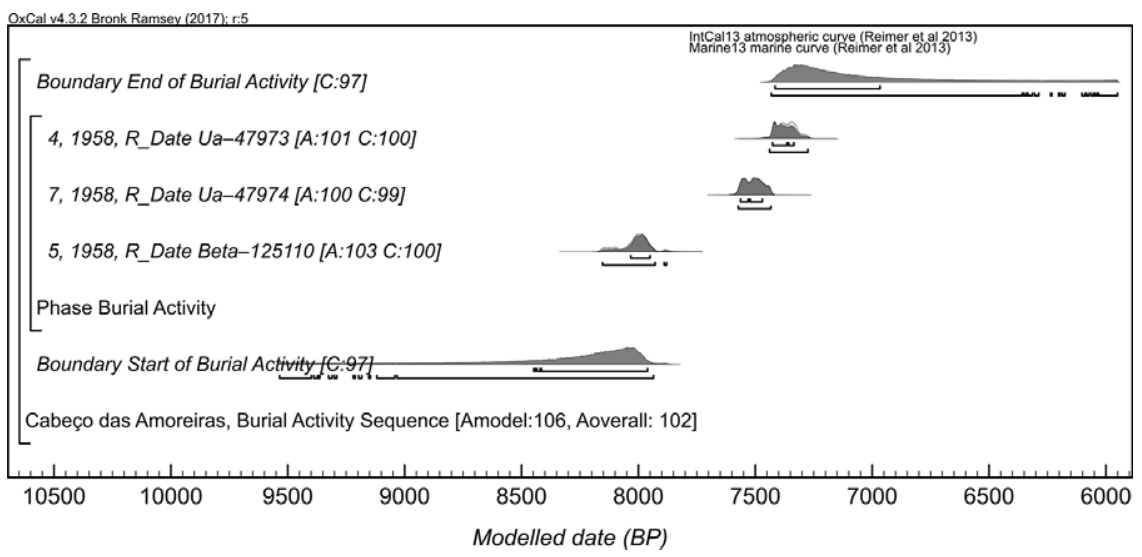

Figure 9 Chronological model for the burial activity at Cabeço das Amoreiras, Sado valley.

López-Dóriga et al. 2016). The death of this individual is estimated to have been between $8152-$ $7860 \mathrm{cal}$ BP (Table 2). The construction of a chronological model for the burial activity at Poças de $\mathrm{S}$. Bento requires further ${ }^{14} \mathrm{C}$ dates on human bone.

\section{Cabeço das Amoreiras}

The chronological model was built on three ${ }^{14} \mathrm{C}$ dates (Figure 9). The measurement Beta125110 was calibrated with the recently published IRMS-based $\delta^{13} \mathrm{C}$ value (Table 2). Despite the low number of dates this model can be considered representative of the assemblage, because the six burials from this site were found in one stratigraphic layer and lie in proximity (Peyroteo Stjerna 2016a). These burials were expected to be coeval, however, the model suggests that the burial episodes were spread over time. Despite the scattering, all dates introduced in the model show good agreement and the model did not consider any outliers. The earliest burial (5, Beta-125110) is estimated to have been between $8153-7880 \mathrm{cal} B P$, while the most recent use of the site for burial practice is dated several centuries later, 7439-7275 cal BP (4, Ua-47973). At Cabeço das Amoreiras, burials were not frequent, but the practice continued over a long period of time.

\section{Vale de Romeiras}

Only three skeletons out of 15 provided ${ }^{14} \mathrm{C}$ measurements within the accepted quality ranges (Cunha et al. 2002; Peyroteo Stjerna 2016a). Furthermore, the chronological model is limited to two ${ }^{14} \mathrm{C}$ dates (Figure 10, Table 2), because one of the skeletons (8, Ua-46968) has a surprising modern age and is out of the scope of this study (Table S1.1). This is a small number of reliable measurements compared with the MNI (26) buried in the site. Although new measurements should be tried in the future, this preliminary model provides valuable indications about the burial activity at Romeiras. The earliest period is estimated to have been between $8543-8334 \mathrm{cal} \mathrm{BP}$, as indicated by the burial of individual 19 (Ua-46972) found on the basal sand outside the shell midden area (Peyroteo Stjerna 2016a). The second date (9, Ua-47983) is several centuries later, with a posterior density estimate of $7575-7429 \mathrm{cal}$ BP. This burial is in the shell midden area and was excavated in the bedrock. The two measurements indicate a long duration of burial activity but it is unknown if the practice was frequent during certain periods or scattered over a long period 


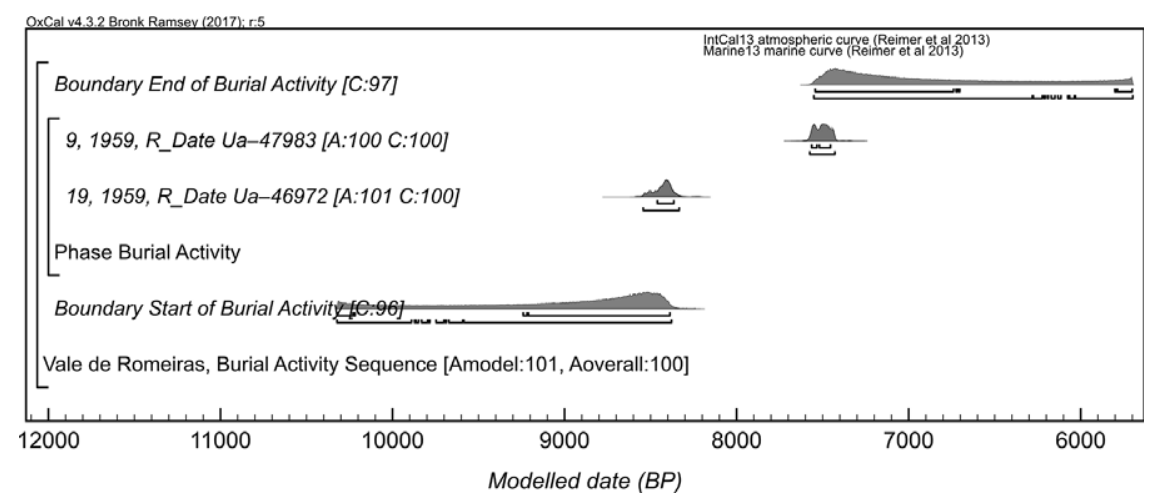

Figure 10 Chronological model for the burial activity at Vale de Romeiras, Sado valley.

of time. Despite the apparent scattering, the two dates show good agreement and the model did not indicate any outliers.

These results indicate that the burials at Vale de Romeiras do not represent one coeval group, contra earlier suggestions of a synchronic burial ground, based on the spatial arrangement of the burials, organized in a semicircle (Arnaud 1989). Nevertheless, these dates do not invalidate this suggestion, which should be reformulated to focus on possible synchronic burial subgroups within the burial ground.

\section{Cabeço do Pez}

The chronological model was built on six ${ }^{14} \mathrm{C}$ dates, one of which is new, from skeletons excavated in 1956 from the two main burial areas (Figure 11, Table 2). The three ${ }^{14} \mathrm{C}$ measurements available for individual 4 (Sac-1558, Beta-125109, and Beta-447690) were calibrated using the OxCal function $R_{-}$Combine and the only IRMS-based $\delta^{13} \mathrm{C}$ value (Beta-447690). This is a relatively low number of samples when compared with the MNI (32-36) buried in the site. Nevertheless, the ${ }^{14} \mathrm{C}$ measurements obtained from both areas are coeval within a calibrated range of ca. $7680-7500$ cal BP. At Cabeço do Pez, during the Mesolithic, the burial activity concentrates in a restricted period, indicating a remarkable high frequency of burial practice at the site, over a relatively short period of time.

The site was also active in the Middle Neolithic for burial, as indicated by the date of the isolated burial of a child (2, Ua-46930), 6446-6220 cal BP. The chronology of this burial is a strong argument supporting the already suggested interpretation (Arnaud 2000) of Cabeço do Pez as a shell midden developing during the Late Mesolithic with later activity at the site, as indicated by the fragments of Neolithic pottery excavated from the upper layers on top of the shell midden (Diniz and Cubas 2015).

\section{Várzea da Mó}

The burial activity at Várzea da Mó is dated by the death of the only individual buried at the site, which is estimated to have been between 7315-7026 cal BP (Table 2). 


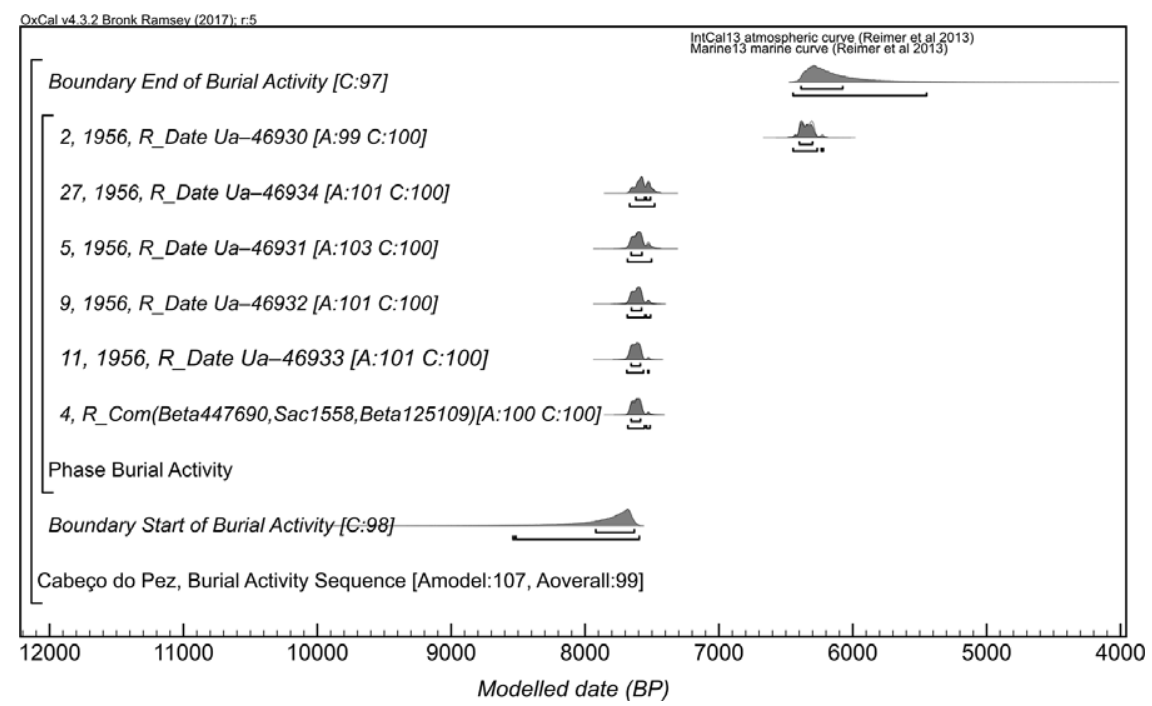

Figure 11 Chronological model for the burial activity at Cabeço do Pez, Sado valley.

\section{Fiais}

The new ${ }^{14} \mathrm{C}$ measurement dates the death of this individual to have been between 7693 7481 cal BP (Table 2) and confirms the Mesolithic chronology of the human activity.

\section{Vale Boi}

The loose human tooth excavated at Vale Boi is dated between 8397-8028 cal BP (Table 2). This date demonstrates the Late Mesolithic activity at the site; but its funerary nature is unknown.

\section{DISCUSSION}

\section{Chronological Boundaries}

Archaeological and ${ }^{14} \mathrm{C}$ evidence suggest that the burial activity of the last hunter-gatherers of southwestern Iberia started with the first human burials being placed in the Sado valley at Vale de Romeiras between $8543-8334 \mathrm{cal} B P$, as indicated by the burial of individual 19. This is an isolated early date followed by the first burials in the Tagus valley at Moita do Sebastião, ca. 8300-7900 cal BP. Around this time, hunter-gatherers were active outside these river valleys, as the ${ }^{14} \mathrm{C}$ date on the loose human tooth at Vale Boi suggests (8397-8028 cal BP), however the funerary nature of this activity is unknown.

Remarkably, the burial activity started simultaneously at several sites between ca. 8150 7860 cal BP, both in the Tagus and Sado valleys, as illustrated by the burials at Cabeço da Arruda (6, 8156-7874 cal BP), Arapouco (2A, 8158-7971 cal BP), Poças de S. Bento (14, 8152-7860 cal BP) and Cabeço das Amoreiras (5, 8153-7880 cal BP). The burial activity at Cabeço da Amoreira and Cova da Onça in the Tagus valley does not seem to have started before ca. 7900-7600 cal BP (Figure 12). 
Table 2 Human bone collagen samples analyzed in this study: 76 samples from 70 individuals. The posterior density estimates derive from Bayesian modeling (95\% probability) outlined in OxCal 4.3 (Bronk Ramsey 2009). In the case of sites with one ${ }^{14} \mathrm{C}$ date, an independent event calibration is used ( $95 \%$ confidence). Protein carbon contribution of marine foods towards bone collagen and associated uncertainties (\% marine, SD) were estimated from the measured $\delta^{13} \mathrm{C}$ value and outlined in FRUITS 3.0 (Fernandes et al. 2014). Abbreviations: not published (n/p), not determined (n/d), standard deviation (SD), not available (n/a) but reported to be within the accepted quality range of 2.9-3.6 (Lubell et al. 1994).

\begin{tabular}{|c|c|c|c|c|c|c|c|c|c|c|c|c|c|c|c|c|c|c|}
\hline \multirow[b]{2}{*}{ Region } & \multirow[b]{2}{*}{ Site } & \multicolumn{6}{|c|}{ Identification of the human remains } & \multicolumn{6}{|c|}{ Measurements } & \multicolumn{4}{|c|}{ Calibration } & \multirow[b]{2}{*}{ References } \\
\hline & & Ind. & Age & Sex & Bone & $\begin{array}{l}\text { Excav., } \\
\text { Museum }\end{array}$ & Context & Lab no. & $\begin{array}{c}{ }^{14} \mathrm{C} \\
\text { Age } \\
\text { BP }\end{array}$ & SD & $\begin{array}{c}\delta^{13} \mathrm{C} \\
(\%) \\
\text { VPDB }\end{array}$ & $\begin{array}{l}\delta^{15} \mathrm{~N} \\
(\% 0) \\
\text { AIR }\end{array}$ & $\begin{array}{l}\mathrm{C}: \\
\mathrm{N}\end{array}$ & $\begin{array}{c}\% \\
\text { marine }\end{array}$ & SD & $\begin{array}{c}\text { Mod } \\
\text { cal } \\
(95 \\
\text { probal }\end{array}$ & $\begin{array}{l}\text { leled } \\
\text { BP } \\
\% \% \\
b i l i t y / \\
\text { lence) }\end{array}$ & \\
\hline Tagus, Muge & $\begin{array}{l}\text { Moita do } \\
\text { Sebastião }\end{array}$ & $\mathrm{CT}$ & Adult & $\mathrm{M}$ & $\mathrm{n} / \mathrm{p}$ & 19th c., MG & Basal sand? & TO-135 & 6810 & 70 & -15.3 & 13.4 & $\mathrm{n} / \mathrm{a}$ & 50 & 11 & 7642 & 7415 & Lubell et al. 1994 \\
\hline Tagus, Muge & $\begin{array}{l}\text { Moita do } \\
\text { Sebastião }\end{array}$ & 33 & Adult & $\mathrm{F}$ & Tibia-R & $\begin{array}{l}\text { 1952-1954, } \\
\text { MHNC }\end{array}$ & Basal sand & Ua-46270 & 6743 & 44 & -18.4 & 10.5 & 3.2 & $\begin{array}{l}M o d \\
18\end{array}$ & $\begin{array}{r}\text { del } 2 \\
10\end{array}$ & $\begin{array}{l}7591 \\
7651\end{array}$ & $\begin{array}{l}7416 \\
7445\end{array}$ & $\begin{array}{c}- \\
\text { Peyroteo Stjerna } \\
2016 \mathrm{a}\end{array}$ \\
\hline Tagus, Muge & $\begin{array}{l}\text { Moita do } \\
\text { Sebastião }\end{array}$ & 10 & $\begin{array}{l}\text { Adult, } \\
30-50 \text { yrs }\end{array}$ & $\mathrm{F}$ ? & Tibia-L & $\begin{array}{l}\text { 1952-1954, } \\
\text { MHNC }\end{array}$ & Basal sand & Ua-47978 & 6753 & 46 & -18.2 & 9.0 & 3.4 & $\begin{array}{l}\text { Mod } \\
20\end{array}$ & $\begin{array}{r}\text { del } 2 \\
10\end{array}$ & $\begin{array}{l}7589 \\
7653\end{array}$ & $\begin{array}{l}7438 \\
7451\end{array}$ & $\begin{array}{c}- \\
\text { Peyroteo Stjerna } \\
\text { 2016a }\end{array}$ \\
\hline Tagus, Muge & $\begin{array}{l}\text { Moita do } \\
\text { Sebastião }\end{array}$ & 15 & $\begin{array}{c}\text { Adult, } \\
25-35 \text { yrs }\end{array}$ & $\mathrm{M}$ & Tibia-R & $\begin{array}{l}\text { 1952-1954, } \\
\text { MHNC }\end{array}$ & Basal sand & Ua-46265 & 6986 & 40 & -17.9 & 10.2 & 3.2 & $\begin{array}{l}\text { Mod } \\
22\end{array}$ & $\begin{array}{r}\text { del } 2 \\
11\end{array}$ & $\begin{array}{l}7590 \\
7842\end{array}$ & $\begin{array}{l}7436 \\
7586\end{array}$ & $\begin{array}{c}- \\
\text { Peyroteo Stjerna } \\
2016 \mathrm{a}\end{array}$ \\
\hline Tagus, Muge & $\begin{array}{l}\text { Moita do } \\
\text { Sebastião }\end{array}$ & 30 & Adult & $\mathrm{M}$ & Humerus-R & $\begin{array}{l}\text { 1952-1954, } \\
\text { MHNC }\end{array}$ & Basal sand & Ua-47981 & 7058 & 44 & -17.4 & 9.8 & 3.2 & $\begin{array}{l}\text { Mod } \\
27\end{array}$ & $\begin{array}{r}\text { del } 2 \\
11\end{array}$ & $\begin{array}{l}7861 \\
7927\end{array}$ & $\begin{array}{l}7703 \\
7619\end{array}$ & $\begin{array}{c}- \\
\text { Peyroteo Stjerna } \\
2016 \mathrm{a}\end{array}$ \\
\hline Tagus, Muge & $\begin{array}{l}\text { Moita do } \\
\text { Sebastião }\end{array}$ & 18 & Adult & $\mathrm{M}$ & Tibia-R & $\begin{array}{l}\text { 1952-1954, } \\
\text { MHNC }\end{array}$ & Basal sand & Ua-46266 & 7095 & 45 & -16.9 & 10.8 & 3.1 & $\begin{array}{l}\text { Mod } \\
32\end{array}$ & $\begin{array}{r}\text { del } 2 \\
11\end{array}$ & $\begin{array}{l}7872 \\
7929\end{array}$ & $\begin{array}{l}7704 \\
7629\end{array}$ & $\begin{array}{c}- \\
\text { Peyroteo Stjerna } \\
2016 \mathrm{a}\end{array}$ \\
\hline Tagus, Muge & $\begin{array}{l}\text { Moita do } \\
\text { Sebastião }\end{array}$ & 17 & Adult & $\mathrm{M}$ & Femur-R & $\begin{array}{l}\text { 1952-1954, } \\
\text { MHNC }\end{array}$ & Basal sand & Ua-47980 & 7105 & 42 & -16.8 & 9.5 & 3.1 & $\begin{array}{l}M o d \\
33\end{array}$ & $\begin{array}{r}\text { del } 2 \\
12\end{array}$ & $\begin{array}{l}7875 \\
7933\end{array}$ & $\begin{array}{l}7705 \\
7636\end{array}$ & $\begin{array}{c}- \\
\text { Peyroteo Stjerna } \\
2016 \mathrm{a}\end{array}$ \\
\hline Tagus, Muge & $\begin{array}{l}\text { Moita do } \\
\text { Sebastião }\end{array}$ & 22 & $\begin{array}{l}\text { Subadult, } \\
\text { ca. } 2 \text { yrs }\end{array}$ & $\mathrm{n} / \mathrm{d}$ & Femur-R & $\begin{array}{l}\text { 1952-1954, } \\
\text { MHNC }\end{array}$ & Basal sand & Ua-46267 & 7120 & 43 & -16.9 & 12.8 & 3.2 & $\begin{array}{l}M o d \\
33\end{array}$ & $\begin{array}{r}\text { del } 2 \\
14\end{array}$ & $\begin{array}{l}7878 \\
7942\end{array}$ & $\begin{array}{l}7705 \\
7633\end{array}$ & $\begin{array}{c}- \\
\text { Peyroteo Stjerna } \\
2016 \mathrm{a}\end{array}$ \\
\hline Tagus, Muge & $\begin{array}{l}\text { Moita do } \\
\text { Sebastião }\end{array}$ & 5 & Adult & M & Long bone-R & $\begin{array}{l}\text { 1952-1954, } \\
\text { MHNC }\end{array}$ & Basal sand & Ua-47977 & 7138 & 42 & -16.9 & 9.3 & 3.1 & $\begin{array}{l}\mathrm{Mod} \\
32\end{array}$ & $\begin{array}{r}\text { del } 2 \\
11\end{array}$ & $\begin{array}{l}7903 \\
7941\end{array}$ & $\begin{array}{l}7709 \\
7675\end{array}$ & $\begin{array}{c}- \\
\text { Peyroteo Stjerna } \\
2016 \mathrm{a}\end{array}$ \\
\hline Tagus, Muge & $\begin{array}{l}\text { Moita do } \\
\text { Sebastião }\end{array}$ & 31 & Adult & $\mathrm{F}$ ? & Tibia-R & $\begin{array}{l}\text { 1952-1954, } \\
\text { MHNC }\end{array}$ & Basal sand & Ua-46269 & 7141 & 40 & -17.4 & 10.6 & 3.2 & & $\begin{array}{r}\text { del } 2 \\
11\end{array}$ & $\begin{array}{l}7905 \\
7955\end{array}$ & $\begin{array}{l}7716 \\
7690\end{array}$ & $\begin{array}{c}- \\
\text { Peyroteo Stjerna } \\
2016 \mathrm{a}\end{array}$ \\
\hline Tagus, Muge & $\begin{array}{l}\text { Moita do } \\
\text { Sebastião }\end{array}$ & 34 & $\begin{array}{l}\text { Adult, } \\
\text { mature }\end{array}$ & M & Tibia-R & $\begin{array}{l}\text { 1952-1954, } \\
\text { MHNC }\end{array}$ & Basal sand & Ua-46271 & 7236 & 41 & -16.3 & 11.9 & 3.2 & & $\begin{array}{r}\text { del } 2 \\
11\end{array}$ & $\begin{array}{l}7903 \\
7984\end{array}$ & $\begin{array}{l}7725 \\
7705\end{array}$ & $\begin{array}{c}- \\
\text { Peyroteo Stjerna } \\
\text { 2016a }\end{array}$ \\
\hline Tagus, Muge & $\begin{array}{l}\text { Moita do } \\
\text { Sebastião }\end{array}$ & 41 & Adult & $\mathrm{n} / \mathrm{d}$ & $\mathrm{n} / \mathrm{p}$ & 19th c., MG & Basal sand? & TO-134 & 7160 & 80 & -16.7 & 11.2 & $\mathrm{n} / \mathrm{a}$ & $\begin{array}{l}\text { Mod } \\
34\end{array}$ & $\begin{array}{r}\text { del } 2 \\
12\end{array}$ & $\begin{array}{l}7909 \\
7990\end{array}$ & $\begin{array}{l}7730 \\
7629\end{array}$ & Lubell et al. 1994 \\
\hline
\end{tabular}




\begin{tabular}{|c|c|c|c|c|c|c|c|c|c|c|c|c|c|c|c|c|c|}
\hline \multirow[b]{2}{*}{ Region } & \multirow[b]{2}{*}{ Site } & \multicolumn{6}{|c|}{ Identification of the human remains } & \multicolumn{6}{|c|}{ Measurements } & \multicolumn{3}{|c|}{ Calibration } & \multirow[b]{2}{*}{ References } \\
\hline & & Ind. & Age & Sex & Bone & $\begin{array}{l}\text { Excav., } \\
\text { Museum }\end{array}$ & Context & Lab no. & $\begin{array}{l}{ }^{14} \mathrm{C} \\
\text { Age } \\
\text { BP }\end{array}$ & SD & $\begin{array}{c}\delta^{13} \mathrm{C} \\
(\%) \\
\text { VPDB }\end{array}$ & $\begin{array}{l}\delta^{15} \mathrm{~N} \\
(\% 0) \\
\text { AIR }\end{array}$ & $\begin{array}{l}\mathrm{C}: \\
\mathrm{N}\end{array}$ & $\begin{array}{l}\% \\
\text { marine }\end{array}$ & $\begin{array}{r}\text { Mod } \\
\text { cal } \\
(95 \\
\text { proba } \\
\text { confic }\end{array}$ & $\begin{array}{l}\text { deled } \\
\text { BP } \\
5 \% \\
\text { tbility/ } \\
\text { dence) } \\
\end{array}$ & \\
\hline Tagus, Muge & $\begin{array}{l}\text { Moita do } \\
\text { Sebastião }\end{array}$ & 24 & Adult & $\mathrm{M}$ & $\mathrm{n} / \mathrm{p}$ & 19th c., MG & Basal sand? & TO-132 & 7180 & 70 & -16.8 & 11.9 & $\mathrm{n} / \mathrm{a}$ & $\begin{array}{r}\text { Model } 2 \\
33 \quad 12\end{array}$ & $\begin{array}{l}7902 \\
8000\end{array}$ & $\begin{array}{l}7716 \\
7669\end{array}$ & $\begin{array}{c}- \\
\text { Lubell et al. } 1994\end{array}$ \\
\hline Tagus, Muge & $\begin{array}{l}\text { Moita do } \\
\text { Sebastião }\end{array}$ & 22 & Adult & $\mathrm{F}$ & $\mathrm{n} / \mathrm{p}$ & 19th c., MG & Basal sand? & TO-131 & 7240 & 70 & -16.1 & 12.2 & $\mathrm{n} / \mathrm{a}$ & $\begin{array}{r}\text { Model } 2 \\
41 \quad 11\end{array}$ & $\begin{array}{l}7905 \\
8009\end{array}$ & $\begin{array}{l}7721 \\
7679\end{array}$ & $\begin{array}{l}- \\
\text { Lubell et al. } 1994\end{array}$ \\
\hline Tagus, Muge & $\begin{array}{l}\text { Moita do } \\
\text { Sebastião }\end{array}$ & 29 & Adult & $\mathrm{F}$ & $\mathrm{n} / \mathrm{p}$ & 19th c., MG & Basal sand? & TO-133 & 7200 & 70 & -16.9 & 10.4 & $\mathrm{n} / \mathrm{a}$ & $\begin{array}{r}\text { Model } 2 \\
32 \quad 11\end{array}$ & $\begin{array}{l}7905 \\
8009\end{array}$ & $\begin{array}{l}7725 \\
7684\end{array}$ & Lubell et al. 1994 \\
\hline Tagus, Muge & $\begin{array}{l}\text { Moita do } \\
\text { Sebastião }\end{array}$ & 25 & $\begin{array}{l}\text { Subadult, } \\
\text { ca. } 1 \text { yr }\end{array}$ & $\mathrm{n} / \mathrm{d}$ & Tibia & $\begin{array}{l}\text { 1952-1954, } \\
\text { MHNC }\end{array}$ & Basal sand & Ua- 46268 & 7243 & 45 & -16.2 & 14.0 & 3.2 & $\begin{array}{r}\text { Model } 2 \\
40 \quad 15\end{array}$ & $\begin{array}{l}7906 \\
8010\end{array}$ & $\begin{array}{l}7725 \\
7685\end{array}$ & $\begin{array}{c}- \\
\text { Peyroteo Stjerna } \\
\text { 2016a }\end{array}$ \\
\hline Tagus, Muge & $\begin{array}{l}\text { Moita do } \\
\text { Sebastião }\end{array}$ & 7 & Adult & $\mathrm{F}$ & Temporal & $\begin{array}{c}\text { 1952-1954, } \\
\text { MHNC }\end{array}$ & Basal sand & Beta-447682 & 7280 & 40 & -17.4 & 10.4 & 3.3 & $\begin{array}{r}\text { Model } 2 \\
27 \quad 11\end{array}$ & $\begin{array}{l}7907 \\
8147\end{array}$ & $\begin{array}{l}7725 \\
7825\end{array}$ & $\begin{array}{c}- \\
\text { This paper }\end{array}$ \\
\hline Tagus, Muge & $\begin{array}{l}\text { Moita do } \\
\text { Sebastião }\end{array}$ & 1 & Adult & $\mathrm{n} / \mathrm{d}$ & Tibia-L & $\begin{array}{c}\text { 1952-1954, } \\
\text { MHNC }\end{array}$ & Basal sand & Ua-46263 & 7483 & 48 & -17.0 & 10.5 & 3.2 & \begin{tabular}{rr}
\multicolumn{2}{r}{ Model 2} \\
$31 \quad 11$
\end{tabular} & $\begin{array}{l}8170 \\
8223\end{array}$ & $\begin{array}{l}7931 \\
7957\end{array}$ & $\begin{array}{c}- \\
\text { Peyroteo Stjerna } \\
\text { 2016a }\end{array}$ \\
\hline Tagus, Muge & $\begin{array}{l}\text { Moita do } \\
\text { Sebastião }\end{array}$ & 9 & Adult & $\mathrm{M}$ & Tibia-L & $\begin{array}{c}\text { 1952-1954, } \\
\text { MHNC }\end{array}$ & Basal sand & Ua-46264 & 7621 & 50 & -17.0 & 10.8 & 3.2 & $\begin{array}{r}\text { Model } 2 \\
31 \quad 11\end{array}$ & $\begin{array}{l}8281 \\
8296\end{array}$ & $\begin{array}{l}7998 \\
7995\end{array}$ & $\begin{array}{c}- \\
\text { Peyroteo Stjerna } \\
\text { 2016a }\end{array}$ \\
\hline Tagus, Muge & $\begin{array}{c}\text { Cabeço } \\
\text { da } \\
\text { Amoreira }\end{array}$ & $\begin{array}{l}\text { Burial context } \\
\text { CAM-01-01 }\end{array}$ & ? & $\mathrm{n} / \mathrm{d}$ & $\mathrm{n} / \mathrm{p}$ & 2001 & $\begin{array}{l}\text { Upper layers, } \\
1960 \text { s area, } 0.2- \\
0.6 \mathrm{~m} \text { from the } \\
\text { top }\end{array}$ & Wk-26796 & 6329 & 40 & -16.9 & 12.3 & $\mathrm{n} / \mathrm{p}$ & \begin{tabular}{rr}
\multicolumn{2}{r}{ Model 2} \\
$33 \quad 14$
\end{tabular} & $\begin{array}{l}8344 \\
7418\end{array}$ & $\begin{array}{l}8017 \\
7070\end{array}$ & $\begin{array}{c}- \\
\text { Bicho et al. 2011, } \\
2013\end{array}$ \\
\hline Tagus, Muge & $\begin{array}{c}\text { Cabeço } \\
\text { da } \\
\text { Amoreira }\end{array}$ & $\begin{array}{c}\text { Burial context } \\
\text { CAM-01-01 } \\
\text { (bone 139, main } \\
\text { ind.) }\end{array}$ & Adult & $\mathrm{n} / \mathrm{d}$ & Rib & 2001 & $\begin{array}{l}\text { Upper layers, } \\
1960 \text { s area, } 0.2- \\
0.6 \mathrm{~m} \text { from the } \\
\text { top }\end{array}$ & TO-10225 & 6550 & 70 & -20.1 & 8.2 & 3.4 & $\begin{array}{cc}\text { Model } 2 \\
9 & 6\end{array}$ & $\begin{array}{l}7418 \\
7561\end{array}$ & $\begin{array}{l}6994 \\
7273\end{array}$ & $\begin{array}{c}- \\
\text { Roksandic 2006; } \\
\text { Jackes and Lubell } \\
2015\end{array}$ \\
\hline Tagus, Muge & $\begin{array}{c}\text { Cabeço } \\
\text { da } \\
\text { Amoreira }\end{array}$ & 3 & Adult & $\mathrm{n} / \mathrm{d}$ & Humerus-L & $\begin{array}{l}\text { 1931, } \\
\text { MHNC }\end{array}$ & $\begin{array}{l}\text { Upper layers, } \\
0.20 \mathrm{~m} \text { from the } \\
\text { top, } \mathrm{FG} / 7\end{array}$ & Beta-447686 & 6770 & 40 & -15.7 & 13.0 & 3.4 & \begin{tabular}{rr}
\multicolumn{2}{c}{ Model 2} \\
$46 \quad 11$
\end{tabular} & $\begin{array}{l}7491 \\
7566\end{array}$ & $\begin{array}{l}7263 \\
7305\end{array}$ & $\begin{array}{c}- \\
\text { This paper }\end{array}$ \\
\hline Tagus, Muge & $\begin{array}{c}\text { Cabeço } \\
\text { da } \\
\text { Amoreira }\end{array}$ & 7 & Adult & $\mathrm{n} / \mathrm{d}$ & $\mathrm{n} / \mathrm{p}$ & $\begin{array}{l}1933 \\
\text { MHNC }\end{array}$ & $\begin{array}{l}0.65 \mathrm{~m} \text { from the } \\
\text { top }\end{array}$ & Beta-127450 & 6850 & 40 & -16.5 & 11.9 & $\mathrm{n} / \mathrm{p}$ & $\begin{array}{r}\text { Model } 2 \\
36 \quad 11\end{array}$ & $\begin{array}{l}7507 \\
7649\end{array}$ & $\begin{array}{l}7268 \\
7428\end{array}$ & $\begin{array}{c}- \\
\text { Cunha and } \\
\text { Cardoso } 2001\end{array}$ \\
\hline
\end{tabular}


Table 2 (Continued)

\begin{tabular}{|c|c|c|c|c|c|c|c|c|c|c|c|c|c|c|c|c|c|c|}
\hline \multirow[b]{2}{*}{ Region } & \multirow[b]{2}{*}{ Site } & \multicolumn{6}{|c|}{ Identification of the human remains } & \multicolumn{6}{|c|}{ Measurements } & \multicolumn{4}{|c|}{ Calibration } & \multirow[b]{2}{*}{ References } \\
\hline & & Ind. & Age & Sex & Bone & $\begin{array}{l}\text { Excav., } \\
\text { Museum }\end{array}$ & Context & Lab no. & $\begin{array}{l}{ }^{14} \mathrm{C} \\
\text { Age } \\
\text { BP }\end{array}$ & SD & $\begin{array}{l}\delta^{13} \mathrm{C} \\
(\%) \\
\text { VPDB }\end{array}$ & $\begin{array}{l}\delta^{15} \mathrm{~N} \\
(\% 0) \\
\text { AIR }\end{array}$ & $\begin{array}{l}\mathrm{C}: \\
\mathrm{N}\end{array}$ & $\begin{array}{c}\% \\
\text { marine }\end{array}$ & SD & $\begin{array}{r}\text { Mod } \\
\text { cal } \\
(95 \\
\text { proba } \\
\text { confic }\end{array}$ & $\begin{array}{l}\text { leled } \\
\text { BP } \\
5 \% \\
\text { bility/ } \\
\text { lence) } \\
\end{array}$ & \\
\hline Tagus, Muge & $\begin{array}{c}\text { Cabeço } \\
\text { da } \\
\text { Amoreira }\end{array}$ & 1 & Subadult & $\mathrm{n} / \mathrm{d}$ & Cranial frag. & $\begin{array}{l}\text { 1930, } \\
\text { MHNC }\end{array}$ & Basal sand & Beta- 447683 & 6890 & 30 & -15.3 & 16.1 & 3.3 & $\begin{array}{l}\mathrm{Mod} \\
50\end{array}$ & $\begin{array}{r}d e l 2 \\
15\end{array}$ & $\begin{array}{l}7662 \\
7659\end{array}$ & $\begin{array}{l}7537 \\
7368\end{array}$ & $\begin{array}{l}- \\
\text { This paper }\end{array}$ \\
\hline Tagus, Muge & $\begin{array}{l}\text { Cabeço } \\
\text { da } \\
\text { Amoreira }\end{array}$ & Burial 2011.2 & $\begin{array}{c}\text { Adult, } \\
20-35 \text { yrs }\end{array}$ & $\mathrm{F}$ & Rib & 2011 & Upper layers, $2 \mathrm{~b}$ & Wk-32142 & 6910 & 40 & -15.8 & 12.9 & 3.3 & $\begin{array}{l}\text { Mod } \\
44\end{array}$ & $\begin{array}{r}\text { del } 2 \\
11\end{array}$ & $\begin{array}{l}7662 \\
7660\end{array}$ & $\begin{array}{l}7534 \\
7434\end{array}$ & Bicho et al. 2013 \\
\hline Tagus, Muge & $\begin{array}{l}\text { Cabeço } \\
\text { da } \\
\text { Amoreira }\end{array}$ & $2 ?$ & Subadult & $\mathrm{n} / \mathrm{d}$ & Petrous-R & 1962, MG & $\begin{array}{l}\text { Upper layers, } \\
0.50 \mathrm{~m} \text { from the } \\
\text { top, dark soil }\end{array}$ & Ua-58119 & 6805 & 35 & -18.9 & 9.6 & 3.3 & $\begin{array}{l}M o d \\
14\end{array}$ & $\begin{array}{l}\text { del } 2 \\
9\end{array}$ & $\begin{array}{l}7663 \\
7674\end{array}$ & $\begin{array}{l}7539 \\
7495\end{array}$ & $\stackrel{-}{-}$ \\
\hline Tagus, Muge & $\begin{array}{c}\text { Cabeço } \\
\text { da } \\
\text { Amoreira }\end{array}$ & 10 & Adult & $\mathrm{n} / \mathrm{d}$ & Tibia & $\begin{array}{c}1933, \\
\text { MHNC }\end{array}$ & $\begin{array}{l}\text { Upper layers, } \\
0.25 \mathrm{~m} \text { from the } \\
\text { top, FG/11-12 }\end{array}$ & Beta-447685 & 6970 & 30 & -16.4 & 11.9 & 3.3 & $\begin{array}{l}M o d \\
37\end{array}$ & $\begin{array}{r}\text { del } 2 \\
11\end{array}$ & $\begin{array}{l}7664 \\
7743\end{array}$ & $\begin{array}{l}7559 \\
7506\end{array}$ & $\stackrel{-}{-}$ \\
\hline Tagus, Muge & $\begin{array}{c}\text { Cabeço } \\
\text { da } \\
\text { Amoreira }\end{array}$ & $3 ?$ & Subadult & $\mathrm{n} / \mathrm{d}$ & Temporal-L & 1962, MG & $\begin{array}{l}\text { Upper layers, } \\
0.50 \mathrm{~m} \text { from the } \\
\text { top, dark soil }\end{array}$ & Beta-447688 & 7040 & 30 & -15.3 & 13.0 & 3.3 & & $\begin{array}{r}\text { del } 2 \\
11\end{array}$ & $\begin{array}{l}7670 \\
7753\end{array}$ & $\begin{array}{l}7563 \\
7501\end{array}$ & $\stackrel{-}{-}$ \\
\hline Tagus, Muge & $\begin{array}{l}\text { Cabeço } \\
\text { da } \\
\text { Amoreira }\end{array}$ & 6 & Adult & $\mathrm{n} / \mathrm{d}$ & Radius-L & $\begin{array}{l}\text { 1933, } \\
\text { MHNC }\end{array}$ & $\begin{array}{l}1.3 \mathrm{~m} \text { from the } \\
\text { top }\end{array}$ & Ua-56456 & 6984 & 32 & -16.4 & 13.8 & 3.4 & $\begin{array}{l}M o d \\
37\end{array}$ & $\begin{array}{r}\text { del } 2 \\
11\end{array}$ & $\begin{array}{l}7671 \\
7760\end{array}$ & $\begin{array}{l}7561 \\
7515\end{array}$ & $\begin{array}{c}- \\
\text { This paper }\end{array}$ \\
\hline Tagus, Muge & $\begin{array}{c}\text { Cabeço } \\
\text { da } \\
\text { Amoreira }\end{array}$ & Burial 2012.3 & $\begin{array}{l}\text { Adult, } \\
>40 \mathrm{yrs}\end{array}$ & M & $\mathrm{n} / \mathrm{p}$ & 2012 & Upper layers, $2 \mathrm{~b}$ & Wk-35718 & 7056 & 34 & -15.4 & 13.3 & 3.3 & $\begin{array}{l}\text { Mod } \\
49\end{array}$ & $\begin{array}{r}\text { del } 2 \\
11\end{array}$ & $\begin{array}{l}7670 \\
7782\end{array}$ & $\begin{array}{l}7565 \\
7518\end{array}$ & $\begin{array}{l}\text { Umbelino et al. } \\
2015\end{array}$ \\
\hline Tagus, Muge & $\begin{array}{c}\text { Cabeço } \\
\text { da } \\
\text { Amoreira }\end{array}$ & $\begin{array}{c}\text { no ID. } \\
\text { Bone } 154936\end{array}$ & Adult & $\mathrm{n} / \mathrm{d}$ & Temporal & $\begin{array}{l}\text { 1930s, } \\
\text { MHNC }\end{array}$ & unknown & Beta-447687 & 7090 & 40 & -15.9 & 12.4 & 3.3 & $\begin{array}{l}\operatorname{Mod} \\
43\end{array}$ & $\begin{array}{r}\text { del } 2 \\
11\end{array}$ & $\begin{array}{l}7673 \\
7831\end{array}$ & $\begin{array}{l}7564 \\
7580\end{array}$ & $\begin{array}{c}- \\
\text { This paper }\end{array}$ \\
\hline Tagus, Muge & $\begin{array}{c}\text { Cabeço } \\
\text { da } \\
\text { Amoreira }\end{array}$ & Burial 2011.1 & $\begin{array}{l}\text { Subadult, } \\
2-3 \text { yrs }\end{array}$ & $\mathrm{n} / \mathrm{d}$ & Tibia & 2011 & $\begin{array}{l}\text { Basal sand, } \\
1960 \text { s area }\end{array}$ & Wk-32143 & 7132 & 41 & -16.0 & 13.9 & 3.3 & $\begin{array}{l}M o d \\
42\end{array}$ & $\begin{array}{r}\text { del } 2 \\
15\end{array}$ & $\begin{array}{l}7682 \\
7906\end{array}$ & $\begin{array}{l}7567 \\
7577\end{array}$ & $\begin{array}{c}- \\
\text { Bicho et al. } 2013\end{array}$ \\
\hline Tagus, Muge & $\begin{array}{c}\text { Cabeço } \\
\text { da } \\
\text { Amoreira }\end{array}$ & 9 & Subadult & $\mathrm{n} / \mathrm{d}$ & Temporal & $\begin{array}{l}1933, \\
\text { MHNC }\end{array}$ & $\begin{array}{l}\text { Deep layer, ca. } \\
0.9 \mathrm{~m} \text { from the } \\
\text { top, } \mathrm{HI} / 10\end{array}$ & Beta-447684 & 7160 & 40 & -16.3 & 11.9 & 3.3 & $\begin{array}{l}M o d \\
39\end{array}$ & $\begin{array}{r}\text { del } 2 \\
11\end{array}$ & $\begin{array}{l}7925 \\
7914\end{array}$ & $\begin{array}{l}7689 \\
7642\end{array}$ & $\begin{array}{c}- \\
\text { This paper }\end{array}$ \\
\hline
\end{tabular}


Table 2 (Continued)

\begin{tabular}{|c|c|c|c|c|c|c|c|c|c|c|c|c|c|c|c|c|c|c|}
\hline \multirow[b]{2}{*}{ Region } & \multirow[b]{2}{*}{ Site } & \multicolumn{6}{|c|}{ Identification of the human remains } & \multicolumn{6}{|c|}{ Measurements } & \multicolumn{4}{|c|}{ Calibration } & \multirow[b]{2}{*}{ References } \\
\hline & & Ind. & Age & Sex & Bone & $\begin{array}{l}\text { Excav., } \\
\text { Museum }\end{array}$ & Context & Lab no. & $\begin{array}{l}{ }^{14} \mathrm{C} \\
\mathrm{Age} \\
\mathrm{BP}\end{array}$ & SD & $\begin{array}{c}\delta^{13} \mathrm{C} \\
(\% \circ) \\
\text { VPDB }\end{array}$ & $\begin{array}{l}\delta^{15} \mathrm{~N} \\
(\% 0) \\
\text { AIR }\end{array}$ & $\begin{array}{l}\mathrm{C}: \\
\mathrm{N}\end{array}$ & $\begin{array}{c}\% \\
\text { marine }\end{array}$ & SD & $\begin{array}{c}\text { Mod } \\
\text { cal } \\
(95 \\
\text { probal } \\
\text { confid }\end{array}$ & $\begin{array}{l}\text { leled } \\
\text { BP } \\
\% \% \\
b i l i t y / \\
\text { lence) }\end{array}$ & \\
\hline & \multirow{4}{*}{$\begin{array}{l}\text { Cabeço } \\
\text { da } \\
\text { Amoreira }\end{array}$} & \multirow{4}{*}{ CAM-00-01 } & \multirow{4}{*}{$\begin{array}{l}\text { Subadult, } \\
4 \text { yrs } \pm 12 \\
\text { months }\end{array}$} & & & & & & & & & & & \multicolumn{2}{|c|}{ Model 2} & 7925 & 7696 & - \\
\hline \multirow[t]{3}{*}{ Tagus, Muge } & & & & \multirow[t]{3}{*}{$\mathrm{n} / \mathrm{d}$} & - & 2000 & \multirow[t]{3}{*}{$\begin{array}{l}\text { Basal sand, } \\
\text { 1960s area }\end{array}$} & $\begin{array}{l}\text { Rcomb: } \\
\text { TO-11819-R, } \\
\text { UOC-913 }\end{array}$ & 7329 & 45 & - & - & - & 42 & 15 & 7976 & 7664 & - \\
\hline & & & & & Rib & & & TO-11819-R & 7300 & 80 & -16.4 & $12.7^{*}$ & $\mathrm{n} / \mathrm{a}$ & 38 & 15 & - & - & $\begin{array}{l}\text { Meiklejohn 2009; } \\
\text { *M. Jackes, pers. } \\
\text { comm. }\end{array}$ \\
\hline & & & & & Rib & & & UOC-913 & 7341 & 53 & -15.7 & 12.5 & 3.2 & $\begin{array}{l}46 \\
\text { Modc }\end{array}$ & $\begin{array}{r}15 \\
\text { lel } 2\end{array}$ & $\begin{array}{c}- \\
7975\end{array}$ & $\begin{array}{c}- \\
7692\end{array}$ & $\begin{array}{c}\text { Jackes et al. } 2016 \\
-\end{array}$ \\
\hline Tagus, Muge & $\begin{array}{l}\text { Cabeço } \\
\text { da } \\
\text { Arruda }\end{array}$ & $\mathrm{N}$ & Adult, old & M & $\mathrm{n} / \mathrm{p}$ & 19th c., MG & $\begin{array}{l}\text { Upper layers } \\
\text { (based on } \\
\text { sediment matrix) }\end{array}$ & TO-356 & 6360 & 80 & -15.3 & 12.5 & $\mathrm{n} / \mathrm{a}$ & 50 & 11 & 7427 & 7019 & Lubell et al. 1994 \\
\hline Tagus, Muge & $\begin{array}{l}\text { Cabeço } \\
\text { da } \\
\text { Arruda }\end{array}$ & CA-00-01 & $\begin{array}{l}\text { Adult, } \\
18-25 \text { yrs }\end{array}$ & $\mathrm{F}$ & Rib & 2000 & $\begin{array}{c}2.0 \mathrm{~m} \text { from } \\
\text { bottom, } 1964- \\
1965 \text { area }\end{array}$ & TO-10217 & 6620 & 60 & -18.1 & 10.5 & 3.4 & 20 & 10 & 7566 & 7294 & $\begin{array}{l}\text { Roksandic 2006; } \\
\text { Jackes and Lubell } \\
2015\end{array}$ \\
\hline Tagus, Muge & $\begin{array}{l}\text { Cabeço } \\
\text { da } \\
\text { Arruda }\end{array}$ & D & Adult & M & $\mathrm{n} / \mathrm{p}$ & 19th c., MG & Basal sand & TO-355 & 6780 & 80 & -18.9 & 10.3 & $\mathrm{n} / \mathrm{a}$ & 14 & 9 & 7702 & 7426 & Lubell et al. 1994 \\
\hline Tagus, Muge & $\begin{array}{l}\text { Cabeço } \\
\text { da } \\
\text { Arruda }\end{array}$ & 42 & $\begin{array}{l}\text { Adult, } \\
20-24 \text { yrs }\end{array}$ & $\mathrm{F}$ & $\mathrm{n} / \mathrm{p}$ & 19th c., MG & Basal sand & TO-359 & 6960 & 70 & -17.2 & 11.8 & $\mathrm{n} / \mathrm{a}$ & 28 & 11 & 7845 & 7505 & Lubell et al. 1994 \\
\hline Tagus, Muge & $\begin{array}{l}\text { Cabeço } \\
\text { da } \\
\text { Arruda }\end{array}$ & A & Adult & M & $\mathrm{n} / \mathrm{p}$ & 19th c., MG & Basal sand & TO-354 & 6970 & 60 & -19.0 & 12.2 & $\mathrm{n} / \mathrm{a}$ & 14 & 8 & 7921 & 7607 & Lubell et al. 1994 \\
\hline \multirow[t]{2}{*}{ Tagus, Muge } & \multirow[t]{2}{*}{$\begin{array}{l}\text { Cabeço } \\
\text { da } \\
\text { Arruda }\end{array}$} & III & $\begin{array}{l}\text { Subadult, } \\
10-11 \text { yrs }\end{array}$ & M? & - & 19th c., MG & Basal sand & $\begin{array}{l}\text { Rcomb: TO- } \\
\text { 360, Beta- } \\
447681\end{array}$ & 7061 & 38 & - & - & - & 28 & 11 & 7925 & 7624 & - \\
\hline & & & & & $\begin{array}{c}\mathrm{n} / \mathrm{p} \\
\text { Temporal-R }\end{array}$ & & & $\begin{array}{c}\text { TO-360 } \\
\text { Beta-447681 }\end{array}$ & $\begin{array}{l}6990 \\
7070\end{array}$ & $\begin{array}{c}110 \\
40\end{array}$ & $\begin{array}{l}-17.7 \\
-17.0\end{array}$ & $\begin{array}{l}11.2 \\
11.3\end{array}$ & $\begin{array}{l}\mathrm{n} / \mathrm{a} \\
3,3\end{array}$ & $\begin{array}{l}24 \\
31\end{array}$ & $\begin{array}{l}11 \\
11\end{array}$ & - & - & $\begin{array}{l}\text { Lubell et al. } 1994 \\
\text { This paper }\end{array}$ \\
\hline Tagus, Muge & $\begin{array}{l}\text { Cabeço } \\
\text { da }\end{array}$ & 2 & Adult & $\mathrm{F}$ & Radius- $\mathrm{R}$ & $\begin{array}{l}1937 \\
\text { MHNC }\end{array}$ & $\begin{array}{l}0.85-0.95 \mathrm{~m} \\
\text { from bottom }\end{array}$ & Ua-47975 & 7116 & 44 & -16.7 & 9.5 & 3.1 & 34 & 12 & 7937 & 7649 & $\begin{array}{c}\text { Peyroteo Stjerna } \\
\text { 2016a }\end{array}$ \\
\hline Tagus, Muge & $\begin{array}{l}\text { Arruda } \\
\text { Cabeço } \\
\text { da } \\
\text { Arruda }\end{array}$ & CA-00-02 & $\begin{array}{l}\text { Adult, } \\
\text { young }\end{array}$ & $\mathrm{F}$ & Tibia & 2000 & $\begin{array}{l}\text { Bottom, } 1960 \mathrm{~s} \\
\text { area }\end{array}$ & TO-10216 & 7040 & 60 & -17.9 & 10.6 & 3.2 & 22 & 11 & 7930 & 7623 & $\begin{array}{l}\text { Roksandic 2006; } \\
\text { Jackes and Lubell } \\
2015\end{array}$ \\
\hline Tagus, Muge & $\begin{array}{l}\text { Cabeço } \\
\text { da } \\
\text { Arruda }\end{array}$ & 1 & Adult & $\mathrm{F}$ & Tibia-R & $\begin{array}{l}1937, \\
\text { MHNC }\end{array}$ & $\begin{array}{l}1.40 \mathrm{~m} \text { from } \\
\text { bottom }\end{array}$ & Ua-46272 & 7166 & 41 & -16.6 & 11.2 & 3.1 & 35 & 11 & 7949 & 7684 & $\begin{array}{c}\text { Peyroteo Stjerna } \\
\text { 2016a }\end{array}$ \\
\hline Tagus, Muge & $\begin{array}{l}\text { Cabeço } \\
\text { da } \\
\text { Arruda }\end{array}$ & 3 & Adult & M & Tibia-R & $\begin{array}{l}\text { 1937, } \\
\text { MHNC }\end{array}$ & $\begin{array}{c}1.20 \mathrm{~m} \text { from } \\
\text { bottom }\end{array}$ & Ua-46273 & 7198 & 40 & -17.3 & 10.1 & 3.1 & 27 & 11 & 8006 & 7749 & $\begin{array}{c}\text { Peyroteo Stjerna } \\
2016 \mathrm{a}\end{array}$ \\
\hline
\end{tabular}


Table 2 (Continued)

\begin{tabular}{|c|c|c|c|c|c|c|c|c|c|c|c|c|c|c|c|c|c|c|}
\hline \multirow[b]{2}{*}{ Region } & \multirow[b]{2}{*}{ Site } & \multicolumn{6}{|c|}{ Identification of the human remains } & \multicolumn{6}{|c|}{ Measurements } & \multicolumn{4}{|c|}{ Calibration } & \multirow[b]{2}{*}{ References } \\
\hline & & Ind. & Age & Sex & Bone & $\begin{array}{l}\text { Excav., } \\
\text { Museum }\end{array}$ & Context & Lab no. & $\begin{array}{c}{ }^{14} \mathrm{C} \\
\text { Age } \\
\text { BP }\end{array}$ & SD & $\begin{array}{c}\delta^{13} \mathrm{C} \\
(\% \%) \\
\text { VPDB }\end{array}$ & $\begin{array}{l}\delta^{15} \mathrm{~N} \\
(\% 0) \\
\text { AIR }\end{array}$ & $\begin{array}{l}\mathrm{C}: \\
\mathrm{N}\end{array}$ & $\begin{array}{c}\% \\
\text { marine }\end{array}$ & $\mathrm{SD}$ & $\begin{array}{c}\text { Mod } \\
\text { cal } \\
(95 \\
\text { probal } \\
\text { confid }\end{array}$ & $\begin{array}{l}\text { deled } \\
\text { BP } \\
5 \% \\
\text { bility/ } \\
\text { lence) }\end{array}$ & \\
\hline Tagus, Muge & $\begin{array}{l}\text { Cabeço } \\
\text { da } \\
\text { Arruda }\end{array}$ & 9 & Adult & $\mathrm{n} / \mathrm{d}$ & Tibia & $\begin{array}{l}\text { 1937, } \\
\text { MHNC }\end{array}$ & $\begin{array}{l}0.30 \mathrm{~m} \text { from } \\
\text { bottom }\end{array}$ & Ua-46274 & 7200 & 41 & -17.4 & 10.6 & 3.1 & 27 & 11 & 8009 & 7749 & $\begin{array}{c}\text { Peyroteo Stjerna } \\
2016 \mathrm{a}\end{array}$ \\
\hline Tagus, Muge & $\begin{array}{l}\text { Cabeço } \\
\text { da } \\
\text { Arruda }\end{array}$ & 4 & Adult & $\mathrm{n} / \mathrm{d}$ & Tibia-R & $\begin{array}{c}\text { 1964-1965, } \\
\text { MG }\end{array}$ & Bottom & Ua-47976 & 7261 & 45 & -17.1 & 9.7 & 3.1 & 30 & 11 & 8043 & 7785 & $\begin{array}{c}\text { Peyroteo Stjerna } \\
2016 \mathrm{a}\end{array}$ \\
\hline Tagus, Muge & $\begin{array}{l}\text { Cabeço } \\
\text { da } \\
\text { Arruda }\end{array}$ & 10 & Adult & M & Femur-R & $\begin{array}{l}\text { 1937, } \\
\text { MHNC }\end{array}$ & $\begin{array}{c}0.25 \mathrm{~m} \text { from } \\
\text { bottom, under sk } \\
9\end{array}$ & Ua-46275 & 7263 & 46 & -17.4 & 11.4 & 3.2 & 27 & 11 & 8054 & 7792 & $\begin{array}{c}\text { Peyroteo Stjerna } \\
\text { 2016a }\end{array}$ \\
\hline Tagus, Muge & $\begin{array}{l}\text { Cabeço } \\
\text { da } \\
\text { Arruda }\end{array}$ & 8 & Subadult & $\mathrm{n} / \mathrm{d}$ & Temporal-R & $\begin{array}{l}1937, \\
\text { MHNC }\end{array}$ & $\begin{array}{l}0.30 \mathrm{~m} \text { from } \\
\text { bottom }\end{array}$ & Beta-447680 & 7260 & 30 & -18.1 & 10.9 & 3.2 & 20 & 10 & 8055 & 7851 & This paper \\
\hline Tagus, Muge & $\begin{array}{l}\text { Cabeço } \\
\text { da } \\
\text { Arruda }\end{array}$ & B & Adult & $\mathrm{n} / \mathrm{d}$ & Maxilla & 19th c., MG & unknown & Ua-56457 & 6647 & 32 & -18.3 & 13.6 & 3.6 & 18 & 10 & 8107 & 7848 & This paper \\
\hline \multirow[t]{2}{*}{ Tagus, Muge } & $\begin{array}{l}\text { Cabeço } \\
\text { da } \\
\text { Arruda }\end{array}$ & 6 & Adult & $\mathrm{F} ?$ & - & $\begin{array}{l}1937 \\
\text { MHNC }\end{array}$ & $\begin{array}{l}0.80 \mathrm{~m} \text { from } \\
\text { bottom }\end{array}$ & $\begin{array}{c}\text { Rcomb: Beta- } \\
\text { 127451, AA- } \\
101343\end{array}$ & 7418 & 58 & - & - & - & 35 & 11 & 8156 & 7874 & - \\
\hline & & & & & Long bone & & & Beta-127451 & 7550 & 100 & $\begin{array}{c}\text { Not } \\
\text { IRMS: } \\
-19.9\end{array}$ & - & - & - & - & - & - & $\begin{array}{l}\text { Cunha and } \\
\text { Cardoso } 2001\end{array}$ \\
\hline Tagus, Magos & $\begin{array}{l}\text { Cova da } \\
\text { Onça }\end{array}$ & No ID & Adult & $\mathrm{n} / \mathrm{d}$ & $\begin{array}{l}\text { Fibula-R } \\
\text { Temporal-R }\end{array}$ & $\begin{array}{l}\text { Not clear, } \\
\text { MG }\end{array}$ & unknown & $\begin{array}{l}\text { AA-101343 } \\
\text { Beta-447677 }\end{array}$ & $\begin{array}{l}7351 \\
6680\end{array}$ & $\begin{array}{l}70 \\
30\end{array}$ & $\begin{array}{l}-16.6 \\
-15.7\end{array}$ & $\begin{array}{l}10.9 \\
13.5\end{array}$ & $\begin{array}{l}3.3 \\
3.4\end{array}$ & $\begin{array}{l}35 \\
46\end{array}$ & $\begin{array}{l}11 \\
11\end{array}$ & $\begin{array}{c}- \\
7488\end{array}$ & $\stackrel{-}{7258}$ & $\begin{array}{l}\text { Jackes et al. } 2014 \\
\text { This paper }\end{array}$ \\
\hline Tagus, Magos & $\begin{array}{l}\text { Cova da } \\
\text { Onça }\end{array}$ & Bone 529.323 & $\begin{array}{l}\text { Adult, } \\
\text { mature }\end{array}$ & $\mathrm{n} / \mathrm{d}$ & Temporal-L & $\begin{array}{l}\text { Not clear, } \\
\text { MG }\end{array}$ & unknown & Beta- 447674 & 6860 & 40 & -14.9 & 13.6 & 3.4 & 55 & 11 & 7582 & 7340 & This paper \\
\hline Tagus, Magos & $\begin{array}{l}\text { Cova da } \\
\text { Onça }\end{array}$ & Bone 529.324 & Adult & $\mathrm{n} / \mathrm{d}$ & Temporal-L & $\begin{array}{l}\text { Not clear, } \\
\text { MG }\end{array}$ & unknown & Beta-447675 & 6830 & 40 & -15.8 & 13.2 & 3.3 & 44 & 11 & 7608 & 7375 & This paper \\
\hline Tagus, Magos & $\begin{array}{l}\text { Cova da } \\
\text { Onça }\end{array}$ & Bone 529.587 & Adult & $\mathrm{n} / \mathrm{d}$ & Temporal-L & $\begin{array}{l}\text { Not clear, } \\
\text { MG }\end{array}$ & unknown & Beta-447676 & 7170 & 40 & -16.1 & 11.9 & 3.3 & 41 & 11 & 7920 & 7617 & This paper \\
\hline \multirow[t]{3}{*}{ Sado } & Arapouco & $2 \mathrm{~A}$ & $\begin{array}{l}\text { Adult, } \\
\text { mature }\end{array}$ & $\mathrm{F}$ & - & 1962, MNA & unknown & $\begin{array}{c}\text { Rcomb: Beta- } \\
447689 \text {, Sac- } \\
1560\end{array}$ & 7228 & 30 & - & - & - & 31 & 11 & 8158 & 7971 & - \\
\hline & & & & & Temporal-L & & & Beta-447689 & 7230 & 30 & -17.0 & 12.5 & 3.4 & 31 & 11 & - & - & This paper \\
\hline & & & & & Long bone & & & Sac-1560 & 7200 & 130 & $\begin{array}{l}\text { Not } \\
\text { IRMS: } \\
-16.9\end{array}$ & $\mathrm{n} / \mathrm{d}$ & $\mathrm{n} / \mathrm{d}$ & - & - & - & - & $\begin{array}{l}\text { Cunha and } \\
\text { Umbelino } 2001\end{array}$ \\
\hline Sado & $\begin{array}{l}\text { Poças de } \\
\text { S. Bento }\end{array}$ & 14 & Adult & $\mathrm{F}$ & $\mathrm{n} / \mathrm{p}$ & 2013, MNA & $\begin{array}{l}\text { Basal sand, } \\
\text { SU613 }\end{array}$ & OxA-29113 & 7238 & 35 & -17.2 & 11.3 & $\mathrm{n} / \mathrm{p}$ & 28 & 11 & 8152 & 7860 & $\begin{array}{c}\text { López-Dóriga et al. } \\
2016\end{array}$ \\
\hline Sado & $\begin{array}{c}\text { Cabeço } \\
\text { das } \\
\text { Amoreiras }\end{array}$ & 4 & Adult & M? & Fibula-L & 1958, MNA & $\begin{array}{l}\text { Layer } 4,1.3 \mathrm{~m} \\
\text { from top }\end{array}$ & Ua-47973 & 6484 & 39 & -20.0 & 7.6 & 3.3 & 9 & 7 & 7439 & 7275 & $\begin{array}{c}\text { Peyroteo Stjerna } \\
\text { 2016a }\end{array}$ \\
\hline
\end{tabular}




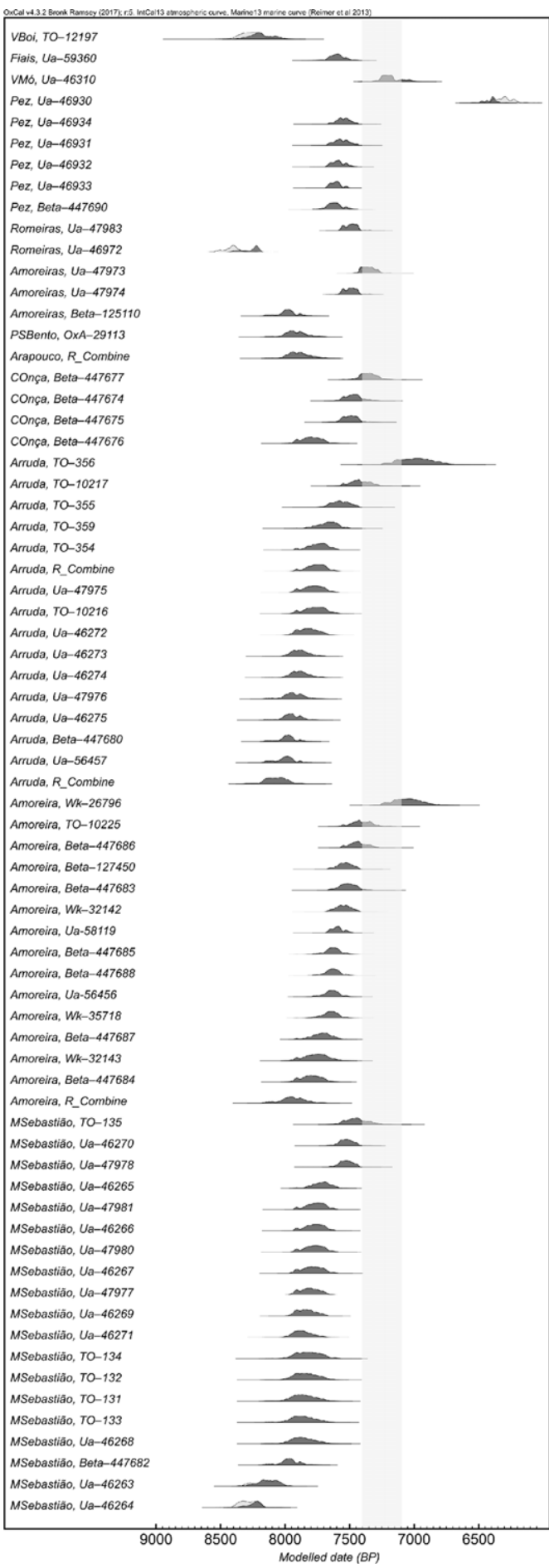

Figure 12 Radiocarbon dates on human bone collagen from the 70 individuals discussed in this paper. Shade: highlights the arrival and expansion of the Neolithic in Portugal, ca. $7400-7100$ cal BP. 
The oldest human burials lie on the sterile sandy layers at the bottom of the shell middens suggesting that the site development was associated with the use of the place for burial practices. Nevertheless, the ${ }^{14} \mathrm{C}$ data also highlights that depth and antiquity of the burial are not always correlated. This is illustrated by older burials in upper layers at Cabeço da Arruda and Amoreira in the Tagus valley, or by the burials with different time ranges but found at the same depth at Cabeço das Amoreiras and Vale de Romeiras in the Sado valley, suggesting a pattern of spatial continuities and discontinuities within the sites.

These early burials were followed by the most active period of burial practice in the Tagus valley. Burial activity was frequent and synchronous at most sites between ca. 7800-7600 cal BP. Around the time the burial activity ended at Moita do Sebastião (ca. 7650-7450 cal BP), it continued at Arruda, Amoreira and Cova da Onça between ca. 7500-7300 cal BP. This activity was coeval with burials in the Sado valley at Vale de Romeiras (9, 7575-7429 cal BP) and at Cabeço das Amoreiras (7, 7573-7434 cal BP). This is also when the burial activity started and was frequent at Cabeço do Pez in the Sado valley between ca. 7680$7500 \mathrm{cal}$ BP. Around this time, hunter-gatherer activity is noted outside the Tagus and Sado valleys, as illustrated by the remains at Fiais in the Mira valley (7693-7481 cal BP). Whether this behavior was related to funerary practice, or other practices involving the manipulation of human remains is unclear.

After ca. 7400 cal BP, the burial activity was less frequent in both Tagus and Sado valleys, ending between $7488-7258 \mathrm{cal} \mathrm{BP}$ at Cova da Onça (Tagus, Magos) and between 7439 $7275 \mathrm{cal} \mathrm{BP}$ at Cabeço das Amoreiras (Sado). The last burials in the Tagus valley range between ca. 7400-7000 cal BP at Amoreira (CAM-01-01) and Arruda (N). This final activity is coeval with the only burial known at Várzea da Mó which is also the last burial event in Mesolithic context in the Sado valley, ranging between 7315-7026 cal BP.

\section{Neolithic Burial Activity?}

The last phase of burial activity in the shell middens is contemporary with the earliest Neolithic sites in Portugal and with human remains found in Early Neolithic contexts, mostly in caves, ca. 7400-7100 cal BP, e.g. Caldeirão, Correio-Mor, Cisterna, and Lameiras (López-Dóriga and Simões 2015; Martins et al. 2015; Carvalho 2018) (Figure 12). It has been argued that the latest burial activity at Cabeço da Amoreira integrated Mesolithic and Neolithic populations (Bicho et al. 2017). This interpretation was based on several observations about the burial context CAM-01-01. Unlike other individuals of the same chronology, the main individual in this context (bone 139, TO-10225) had a terrestrial based diet (Table 2) and was likely non-local as suggested by strontium values (Price 2015). In addition, the allegedly multiple nature of this burial in line with Neolithic practices and the ${ }^{14} \mathrm{C}$ date (7561-7273 cal BP, mod. 1; 7491-7263 cal BP, mod. 2) being coeval with the arrival of the first Neolithic populations in Portugal, would identify this deposition as the burial of Neolithic people. Nevertheless, these arguments do not validate the Neolithic interpretation of this context, in particular if it is analyzed from a multi-site perspective. First, stable isotope values are highly heterogeneous in the Iberian Mesolithic (Cubas et al. 2018), with groups of individuals with a varied range of mixed diets based on marine and terrestrial resources, as well as individuals with a predominantly terrestrial diet, as observed in the Sado valley (Table 2). This heterogeneity within Mesolithic populations could also explain the exogenous strontium values of this individual. Second, as argued earlier, the multiple burial interpretation of this context is not supported by the archaeological evidence 
(see Archaeological Background section above). Finally, this ${ }^{14} \mathrm{C}$ date is coeval with other remains in clear Mesolithic context in the Tagus, Sado and Mira valleys. Also, nothing in any of these recent graves, such as burial position or material culture, indicate that these are the burials of Neolithic individuals instead of Mesolithic hunter-gatherers (Roksandic 2006; Roksandic and Jackes 2014; Peyroteo Stjerna 2016a).

Rather than the simultaneous use of these burial grounds by Mesolithic and Neolithic people, the consistency of later dates in several Mesolithic burial contexts strongly indicates that these sites were repeatedly used for mortuary activities by Mesolithic hunter-gatherers at the onset and establishment of the Neolithic lifestyle in southwestern Iberia, ca. 7400-7000 cal BP.

Later burial activity is evident only at Cabeço do Pez in the Sado valley, by the burial of a child between 6446-6220 cal BP(Ua-46930) outside the two areas with Mesolithic burials. This event is coeval with the early stages of the Middle Neolithic in Portugal ca. 6450-5450 cal BP (Neves and Diniz 2014) and with Neolithic activity at Pez (Arnaud 2000). This episode requires further exploration as it suggests that some sites may have been used occasionally for burial activity after their abandonment by Mesolithic hunter-gatherer populations.

\section{Environmental and Cultural Explanations}

The well-defined chronological and spatial boundaries of the mortuary practice suggest that this relationship with death was particular to these communities. The beginning of the phenomenon coincides with the reconfiguration of the settlement pattern, as well as with other cultural changes in the region that define the Late Mesolithic in the southwestern Iberian Peninsula.

The start of burial activity at the Tagus and Sado valleys corresponds to the first moments of occupation of these sites, ca. $8500-8300 \mathrm{cal} \mathrm{BP}$, and is coeval with sea level rise related environmental changes. In fact, the burial activity was more frequent between ca. 78007600 cal BP, when the inner estuarine environments were well established in the valleys. Although the chronological match between environmental changes and the new settlement pattern is not a coincidence, the social mechanisms allowing this territorial and social reconfiguration remain unclear (Araújo 2015), and need further research. Likewise, the processes leading to the decline and end of burial activity around 7450-7000 cal BP, at both the Tagus and Sado valleys, are poorly understood, and in this case, the environmental factors seem to play a less important role. The decrease of burial activity in the two valleys is coeval with the first phase of the Early Neolithic in Portugal ca. 7450$7250 \mathrm{cal} \mathrm{BP}$, and coincides with environmental changes documented in the Tagus valleys, defined by the contraction of estuarine habitats ca. 7450-5750 cal BP and the establishment of an open landscape around $6950 \mathrm{cal} \mathrm{BP}$. Nevertheless, the socio-cultural explanation for the end of the phenomenon, defined by the expansion of the Neolithic lifestyle, seems to be more compelling, because despite the decline of the environmental conditions, the inner estuaries were still productive and the same mix of favorable habitats remained until ca. $5750 \mathrm{cal}$ BP in the Tagus valley, and ca. $3300 \mathrm{cal}$ BP in the Sado valley.

\section{CONCLUSION}

This chronology of the burial activity of the last hunter-gatherers in southwestern Iberia starts with a paradigm shift contrasting with previous and contemporaneous responses to death in the 
region. This change in funerary practices emerged in the context of settlement reorganization and cultural transformations that define the Late Mesolithic in the region.

Overall, these sites were used for burial activity more or less synchronously. In both the Tagus and Sado valleys, burial activity was more frequent between ca. 7800 and 7450 cal BP. In both valleys, there were early episodes of human burial activity, around $8500-8300$ cal BP, defining the first phases of the Late Mesolithic in Portugal. After 7450 cal BP, the frequency of burial practice decreases dramatically, in both valleys, with a few last episodes not later that ca. 6950 cal BP.

Mechanisms of change that led to the disruption of this paradigm are poorly understood. Archaeological and ${ }^{14} \mathrm{C}$ evidence indicates that local hunter-gatherer burial activity decreases during the expansion of the Neolithic in southwestern Iberia from ca. 7450-7250 cal BP onwards, but hunter-gatherer burial practices continued, though less frequently, showing that diverse social structures and worldviews coexisted for several generations.

The multi-site approach offers a comprehensive perspective, contextualized within regional environmental and cultural developments. This study provides the chronological boundaries for the burial activity of the last hunter-gatherers in southwestern Iberia based on current archaeological and ${ }^{14} \mathrm{C}$ evidence. Burial ${ }^{14} \mathrm{C}$ data suggest a longer chronology for the Late Mesolithic in Portugal than previously suggested, starting around 8500-8300 cal BP and ending ca. $7000 \mathrm{cal} \mathrm{BP}$. This timeframe is based on mortuary activity of Late Mesolithic tradition. The focus on the human burials allows the establishment of chronologies based on strong indicators of human activity, however, other uses of the sites were not considered in the analysis and require further investigation.

\section{ADDENDUM}

Since the writing of this manuscript, a new article has been published reporting new ${ }^{14} \mathrm{C}$ dates on two human burials excavated in 1984 at Samouqueira I (Jackes et al. 2019), on the Portuguese west coast, north of Fiais. The burials date to 7700-7490 cal BP (Individual H1, OxA-36994, 6995 $\pm 36{ }^{14} \mathrm{C}$ BP, $\left.\delta^{13} \mathrm{C}=-15.9 \%, \delta^{15} \mathrm{~N}=15.7 \%, \mathrm{C}: \mathrm{N}=3.3\right)$ and 7690 7475 cal BP (Individual H2, OxA-36936, $7015 \pm 38{ }^{14} \mathrm{C} \mathrm{BP}, \delta^{13} \mathrm{C}=-15.2 \%$, $\delta^{15} \mathrm{~N}=15.7 \%$, $\mathrm{C}: \mathrm{N}=3.3$ ). These burial episodes are coeval with the human remains at Fiais in the Mira valley (7693-7481 cal BP) and with the period of most frequent burial activity in the Tagus and Sado valleys between ca. 7800-7600 cal BP.

\section{ACKNOWLEGMENTS}

The National Museum of Archaeology, Lisbon; the Geological Museum, Lisbon; and the Museum of Natural History and Science, University of Porto, provided the support and samples that made this study possible. Ana Cristina Araújo for insight and assistance in the sample selection, Ana Costa for sharing her research and unpublished paleoenvironmental results, Mary Jackes for providing unpublished ${ }^{15} \mathrm{~N}$ values, Cláudia Umbelino for unpublished information, and Chris Meiklejohn for comments on Table 2. This study benefited from the use of the Portuguese Infrastructure of Scientific Collections (PRISC.pt). 


\section{SUPPLEMENTARY MATERIAL}

To view supplementary material for this article, please visit https://doi.org/10.1017/RDC. 2020.100

\section{REFERENCES}

Ambrose SH. 1993. Isotopic analysis of palaeodiets: methodological and interpretative considerations. In: Sandford MK, editor. Investigations of Ancient Human Tissue. Chemical Analysis in Anthropology. Langhorne: Gordon and Breach Science Publishers. p. 59-130.

Araújo AC. 1997. A indústria lítica do concheiro de Poças de S. Bento (Vale do Sado) no seu contexto regional. O Arqueólogo Port $13-15: 87-159$.

Araújo AC. 2015. A few steps backwards ... in search of the origins of the Late Mesolithic. In: Bicho N, Detry C, Price TD, Cunha E, editors. Muge 150th: the 150th anniversary of the discovery of Mesolithic shellmiddens. Vol. 2. Cambridge: Cambridge Scholars Publishing. p. 1-16.

Arias P, Diniz M, Armendáriz Á, Teira L. 2015. At the edge of the marshes: new approaches to the Sado valley Mesolithiv (Southern Portugal). In: Bicho N, Detry C, Price TD, Cunha E, Bicho $\mathrm{N}$, editors. Muge 150th: the 150th anniversary of the discovery of Mesolithic shellmiddens. Vol. 1. Cambridge: Cambridge Scholars Publishing. p. 301-320.

Arnaud JM. 1988. Projecto de Investigação: o Mesolítico no Centro e Sul de Portugal. Relatório das escavações efectuadas em 1988 no concheiro de Fiais (Odemira).

Arnaud JM. 1989. The Mesolithic communities of the Sado valley, Portugal, in their ecological setting. In: Bonsall C, editor. The Mesolithic in Europe. Papers presented at the third International Symposium. Edinburgh: John Donald Publishers Ltd. p. 614-631.

Arnaud JM. 2000. Os concheiros mesolíticos do vale do Sado e a exploração dos recursos estuarinos (nos tempos pré-históricos e na actualidade). In: Actas do Encontro sobre Arqueologia da Arrábida. Lisboa: Instituto Português de Arqueologia. p. 21-43.

Barradas L. 1936. Concheiros do Vale do Sado. An Fac Ciênc Porto 21:175-179.

Bayliss A. 2009. Rolling out revolution: using radiocarbon dating in archaeology. Radiocarbon 51(1):123-147.

Bayliss A, Ramsey CB, van der Plicht J, Whittle A. 2007. Bradshaw and Bayes: towards a timetable for the Neolithic. Camb Archaeol J. 17(S1):1-28.

Bicho N. 1995. A ocupação epipaleolítica do Abrigo Grande das Bocas, Rio Maior. O Arqueólogo Port. 13/15:53-85.

Bicho N, Cascalheira J, Gonçalves C, Umbelino C, Rivero DG, André L. 2017. Resilience, replacement and acculturation in the Mesolithic/ Neolithic transition: the case of Muge, central Portugal. Quaternary International 446:31-42.

Bicho N, Cascalheira J, Marreiros J, Gonçalves C, Pereira T, Dias R. 2013. Chronology of the Mesolithic occupation of the Muge valley, central Portugal: the case of Cabeço da Amoreira. Quat Int. 308-309:130-139.

Bicho N, Cascalheira J, Marreiros J, Pereira T. 2011. The 2008-2010 excavations of Cabeço da Amoreira, Muge, Portugal. Mesolith Misc. 21(2):3-13.

Bicho N, Umbelino C, Detry C, Pereira T. 2010. The emergence of the Muge Mesolithic shellmiddens (central Portugal) and the $8200 \mathrm{cal}$ yr BP cold event. J Isl Coast Archaeol. 5(1):83-104.

Breuil H, Zbyszewski G. 1947. Révision des industries mésolitiques de Muge et de Magos. Comun Serviços Geológicos Port. XXVIII:149-229.

Bronk Ramsey C. 1995. Radiocarbon calibration and analysis of stratigraphy: the OxCal program. Radiocarbon 37(2):425-430.

Bronk Ramsey C. 2009. Bayesian analysis of radiocarbon dates. Radiocarbon 51(1):337-360.

Cardoso JL, Rolão J. 2000. Prospecções e escavações nos concheiros mesolíticos de Muge e Magos (Salvaterra de Magos): contribuição para a história dos trabalhos arqueológicos efectuados. Estud Arqueol Oeiras. 8:88-240.

Carvalho AF. 2009. O Mesolítico Final em Portugal. El Mesolítico Geométrico En Península Ibérica. Monografias Arqueológicas (44):33-68.

Carvalho AF. 2010. Chronology and geography of the Mesolithic-Neolithic transition in Portugal. In: Armbruester T, Hegewisch M, editors. On pre- and earlier history of Iberia and central Europe. Studies in honour of Philine Kalb. Bonn: Habelt-Verlag. (Studien zur Archäologie Europas). p. 45-61.

Carvalho AF. 2018. When the Mediterranean met the Atlantic. A socio-economic view on Early Neolithic communities in central-southern Portugal. Quaternary International 470:472-484.

Carvalho AF, Dean R, Bicho N, Figueiral I, Petchey F, Davis S, Jackes M, Lubell D, Beukens R, Morales A, et al. 2008. O Neolítico antigo de Vale Boi (Algarve, Portugal): primeiros resultados. In: Actas del IV Congreso del Neolítico Peninsular. Alicante: Museo Arqueológico de Alicante p. 267-274.

Cascalheira J, Paixão E, Marreiros J, Pereira T, Bicho N. 2015. Preliminary techno-typological analysis of the lithic materials from the trench area of 
Cabeço da Amoreira (Muge, Central Portugal). In: Bicho N, Detry C, Price TD, Cunha E, editors. Muge 150th: the 150th anniversary of the discovery of Mesolithic shellmiddens. Vol. 1. Cambridge Scholars Publishing. p. 119-133.

Costa AM, Freitas M da C, Leira M, Costas S, Costa PJ, Andrade C, Bao R, Duarte J, Rodrigues A, Cachão M, et al. 2019. The role of climate, marine influence and sedimentation rates in late-Holocene estuarine evolution (SW Portugal). The Holocene 29(4):622-632.

Cubas M, Peyroteo-Stjerna R, Fontanals-Coll M, Llorente-Rodríguez L, Lucquin A, Craig OE, Colonese AC. 2018. Long-term dietary change in Atlantic and Mediterranean Iberia with the introduction of agriculture: a stable isotope perspective. Archaeol Anthropol Sci. 11: 3825-3836.

Cunha E, Cardoso F. 2001. The osteological series from Cabeço da Amoreira (Muge, Portugal). Bull Mém Société D'Anthropologie Paris 13(34):323-333.

Cunha E, Cardoso F. 2003. New data on Muge shell middens: a contribution to more accurate numbers and dates. Estud Arqueol Muge I: 171-184.

Cunha E, Cardoso F, Umbelino C. 2003. Inferences about Mesolithic life style on the basis of anthropological data. The case of the Portuguese shell middens. In: Larsson L, Kindgren H, Knutsson K, Loeffler D, Åkerlund A, editors. Mesolithic on the Move: papers presented at the Sixth International Conference on the Mesolithic in Europe, Stockholm 2000. Oxford: Oxbow Books. p. 184-188.

Cunha E, Umbelino C. 1997. Abordagem antropológica das comunidades mesolíticas dos Concheiros do Sado. O Arqueólogo Port 13-15: 161-179.

Cunha E, Umbelino C. 2001. Mesolithic People from Portugal: an approach to Sado osteological series. Anthropologie 39(2-3):125-132.

Cunha E, Umbelino C, Cardoso F. 2002. New anthropological data on the mesolithic communities from Portugal: the shell middens from Sado. Human Evolution 17(3-4):187-198.

Delibrias G, Roche J. 1965. Chronologie absolue des amas coquilliers mésolithiques de Muge (Portugal). Comptes Rendus Acad Sci Paris. 260:2005-2006.

DeNiro MJ. 1985. Postmortem preservation and alteration of in vivo bone collagen isotope ratios in relation to palaeodietary reconstruction. Nature 317(6040):806-809.

Detry C. 2007. Paleoecologia e Paleoeconomia do Baixo Tejo no Mesolítico Final: o contributo do estudo dos mamíferos dos concheiros de Muge $[\mathrm{PhD}]$. Salamanca-Lisboa: Universidad de Salamanca and Universidade Autónoma de Lisboa.
Detry C, Cardoso JL. 2010. On some remains of dog (Canis familiaris) from the Mesolithic shellmiddens of Muge, Portugal. J Archaeol Sci. (37):2762-2774.

Diniz M, Arias P. 2012. O povoamento humano do paleo-estuário do Sado (Portugal): problemáticas em torno da ocupação dos concheiros mesolíticos. In: Almeida AC, Bettencourt AMS, Moura D, Monteiro-Rodrigues S, Alves MIC, editors. Mudanças ambientais e interação humana na fachada atlântica ocidental. Coimbra: APEQ/CITCEM/CEGT/CGUP/CCT. p. 139-157.

Diniz M, Arias P, Teira L, Araújo AC, Cubas M, Neves MJ, Nukushina D, Rocha L, CerrilloCuenca E, Fernádez Sánchez P. 2014. Relatório de progresso. Os últimos caçadores-reclectores e os primeiros grupos agro-pastoris no vale do Sado. Estudo arqueológico num contexto regional (SADO-MESO): Poças de S. Bento, Arapouco e Vale de Romeiras (Alcácer do Sal). Ano 4, 2013. Lisboa.

Diniz M, Arias P, Teira L, Araújo AC, Cubas M, Rocha L, Cerrillo-Cuenca E, Vallejjo J, Davis S. 2015. Relatório de progresso. Os últimos caçadores-reclectores e os primeiros grupos agro-pastoris no vale do Sado. Estudo arqueológico num contexto regional (SADOMESO): Poças de S. Bento, Arapouco e Vale de Romeiras (Alcácer do Sal). Ano 4, 2013. Lisboa.

Diniz M, Cubas M. 2015. Pots for Thought: Neolithic Pottery in the Sado Mesolithic Shell Middens. In: Bicho N, Detry C, Price TD, Cunha E, editors. Muge 150th: the 150th anniversary of the discovery of Mesolithic shellmiddens. Vol. 1. Cambridge: Cambridge Scholars Publishing. p. 375-390.

Diniz M, Nukushina D. 2014. CaçadoresRecolectores no Vale do Sado, Ambiente, Recursos e Teconoligia Lítica: O Caso de Arapouco (Alcácer do Sal). Estud Quaternário APEQ. 11:27-38.

Duday H. 2009. The archaeology of the dead: lectures in archaeothanatology. Oxford: Oxbow Books.

Fernandes R. 2015. A Simple(R) model to predict the source of dietary carbon in individual consumers. Archaeometry 58(3):500-512.

Fernandes R, Millard AR, Brabec M, Nadeau M-J, Grootes P. 2014. Food Reconstruction Using Isotopic Transferred Signals (FRUITS): a Bayesian model for diet reconstruction. PLOS ONE 9(2):e87436.

Ferreira OV. 1974. Acerca das cerâmicas neolíticas encontradas na parte superior dos concheiros da região de Muge (Portugal). Comun Serviços Geológicos Port 58:191-196.

Fontanals-Coll M, Subirà ME, Marín-Moratalla N, Ruiz J, Gibaja JF. 2014. From Sado Valley to Europe: Mesolithic dietary practices through 
different geographic distributions. J Archaeol Sci. 50:539-550.

Guiry EJ, Hillier M, Richards MP. 2015. Mesolithic dietary heterogeneity on the European Atlantic coastline: stable isotope insights into huntergatherer diet and subsistence in the Sado Valley, Portugal. Current Anthropology 56(3):460-470.

Hedges REM, Lee-Thorp JA, Tuross NC. 1995. Is tooth enamel carbonate a suitable material for radiocarbon dating? Radiocarbon 37(2):285-290.

Hopkins RJA, Snoeck C, Higham TFG. 2016. When dental enamel is put to the acid test: pretreatment effects and radiocarbon dating. Radiocarbon 58(4):893-904.

Jackes M, Alvim P. 2006. Reconstructing Moita do Sebastião, the first step. In: Bicho N, Carvalho AF, editors. Actas do IV Congresso de arqueologia peninsular: do Epipaleolítico ao Calcolítico na Península Ibérica. Vol. Promontoria Monográfica 4. Faro: Universidade do Algarve. p. 13-25.

Jackes M, Alvim P, Anacleto J, Roksandic M. 2014. New photographic evidence on the 1954 excavations at Moita do Sebastião, Muge, Portugal. In: Roksandic Mirjana, Mendonça S, Eggers S, Burchell M, Klokler D, editors. The cultural dynamics of shell middens and shell mounds: a worldwide perspective. Albuquerque: University of New Mexico Press. p. 131-149.

Jackes M, Lubell D. 2012. Mortuary archaeology of the Muge shell middens. In: Gibaja JF, Carvalho $\mathrm{AF}$, Chambon P, editors. Funerary practices in the Iberian Peninsula from the Mesolithic to the Chalcolithic. Oxford: Archaeopress. (BAR International Series). p. 67-76.

Jackes M, Lubell D. 2015. Muge Mesolithic samples analyzed in Canada, including previously unpublished stable isotope data. Mesolith Misc. 23(2):58-62.

Jackes M, Lubell D, Cardoso HFV, Anacleto JA., Meiklejohn C. 2015. Cabeço da Arruda in the 1860s. In: Bicho N, Detry C, Price TD, Cunha E, editors. Muge 150th: The 150th anniversary of the discovery of Mesolithic shellmiddens. Vol. 1. Cambridge Scholars Publishing. p. 45-58.

Jackes M, Lubell D, Roksandic M. 2016. Reanalysis of a Muge child's bone chemistry: the problem of Amoreira 2000-01. Mesolith Misc. 24(1): 13-18.

Jackes M, Meiklejohn C. 2004. Building a method for the study of the Mesolithic-Neolithic transition in Portugal. Doc Praehist. 31:89-111.

Jackes M, Meiklejohn C. 2008. The paleodemography of central Portugal and the Mesolithic-Neolithic transition. In: Bocquet-Appel J-P, editor. Recent advances in paleodemography: data, techniques, pattterns. Springer Science+Business Media B.V. p. 209-258.

Jackes M, Meiklejohn C, Schulting R, Arias P. 2019. New analyses and dating of partial skeletons from Samouqueira I, Portugal. Mesolith Misc. 27(1):3-26.

van Klinken G. 1999. Bone collagen quality indicators for paleodietary and radiocarbon measurements. J Archaeol Sci. 26:687-695.

Larsson L. 1996. Late Atlantic Settlement in Southern Portugal. Results of an excavation of a Mesolithic shell midden by the River Sado. Curr Swed Archaeol. 4:123-139.

Lentacker A. 1986. Preliminary results of fauna of Cabeço de Amoreira and Cabeço da Arruda (Muge, Portugal). Trab Antropol E Etnologia. 26(1-4):9-26.

Lentacker A. 1994. Fish remains from Portugal: preliminary analysis of the Mesolithic shellmidden sites of Cabeço da Amoreira and Cabeço da Arruda. Ann Mus R Afr Cent Sci Zool. 274:263-271.

López-Dóriga I, Diniz M, Arias P. 2016. Macrobotanical remains and shell-midden formation processes, are they related? The case of Poças de São Bento (Portugal). Archaeol Anthropol Sci. 11(2):469-481

López-Dóriga I, Simões T. 2015. Los cultivos del Neolítico Antiguo de Sintra: Lapiás das Lameiras y São Pedro de Canaferrim: resultados preliminares. In: Gonçalves VS, Diniz M, Sousa AC, editors. Actas do 5 Congresso do Neolítico Peninsular. Lisboa: UNIARQ. (Estudos \& Memórias 8). p. 96-105.

Lubell D, Jackes M, Schwarcz H, Knyf M, Meiklejohn C. 1994. The Mesolithic-Neolithic transition in Portugal: isotopic and dental evidence of diet. J Archaeol Sci. 21:201-216.

Lubell D, Jackes M, Sheppard P, Rowley-Conwy P. 2004. The Mesolithic-Neolithic in the Alentejo: archaeological investigations, 1984-1985. In: From the Mediterranean basin to the Portuguese Atlantic shore: papers in Honor of Anthony Marks. Actas do IV Congresso de Arqueologia Peninsular. Vol. 7. Faro: Universidade do Algarve. (Promonoria Monográfica). p. 209-220.

Marchand G. 2001. Les traditions techniques du Mésolithique final dans le sud du Portugal: les industries lithiques des amas coquilliers de Várzea da Mó et de Cabeço do Rebolador (fouilles M. Heleno). Rev Port Arqueol. 4(2):47-110.

Marques-Gabriel S. 2015. La ictiofauna del Holoceno Inicial y Medio de Portugal. Implicaciones tafonómicas, ecologicas y culturales [PhD thesis]. Madrid: Universidad Autonoma de Madrid.

Martins H, Oms FX, Pereira L, Pike A, Rowsell K, Zilhão J. 2015. Radiocarbon dating the beginning of the Neolithic in Iberia: New Results, New Problems. J Mediterr Archaeol. 28(1):105-131.

Martins JM, Carvalho AF, Monge Soares A. 2008. A calibração das datas de radiocarbono dos esqueletos humanos de Muge. Promontoria Monográfica (6):73-93. 
Martins JM, Monge Soares A. 2013. Marine Radiocarbon Reservoir Effect in Southern Atlantic Iberian Coast. Radiocarbon 55(3): 1123-1134.

Meiklejohn C. 2009. Radiocarbon dating of Mesolithic human remains in Spain. Mesolith Misc. 20(2):2-20.

Meiklejohn C, Roksandic M, Jackes M, Lubell D. 2009. Radiocarbon dating of Mesolithic human remains in Portugal. Mesolith Misc. 20(1):4-16.

Millard AR. 2014. Conventions for reporting radiocarbon determinations. Radiocarbon 56(2):555-559.

Neves C, Diniz M. 2014. Acerca dos cenários da acção: estratégias de implantação e exploração do espaço nos finais do 50 e na primeira metade do 4o milénio A.C. no sul de Portugal. Estud Quaternário APEQ. 11:45-58.

Nukushina D. 2012. Tecno-tipologia lítica e cronometria no Mesolítico final do Vale do Sado: o caso do concheiro das Amoreiras (Alcácer do Sal) [MA thesis]. Lisboa: Universidade de Lisboa.

Paço A. 1938. Novos concheiros do Vale do Tejo. Brotéria 27(1):66-75.

Paula e Oliveira F. 1888. Nouvelles fouilles faites dans les kiokkenmoeddings de la vallée du Tage (posthumous publication). Comun Com Trab Geológicos. 2:57-81.

Pettitt P. 2011. The Palaeolithic origins of human burial. Routledge.

Peyroteo Stjerna R. 2016a. On death in the Mesolithic: or the mortuary practices of the last hunter-gatherers of the south-western Iberian Peninsula, 7th-6th millennium BCE $[\mathrm{PhD}$ thesis]. Uppsala: Uppsala University.

Peyroteo Stjerna R. 2016b. Roots of Death: origins of human burial and the research on early Holocene mortuary practices in the Iberian Peninsula. In: Grünberg JM, Gramsch B, Larsson L, Orschiedt J, Meller H, editors. Mesolithic burials_rites, symbols and social organisation of early postglacial communities. Vol. Band 13/ II. Halle (Saale): Tagungen des Landesmuseums für Vorgeschichte Halle. p. 629-643.

Price TD. 2015. Tracing past human movement: an example from the Muge middens. In: Bicho N, Detry C, Price TD, Cunha E, editors. Muge 150th. The 150th anniversary of the discovery of Mesolithic shellmiddens. Vol. 1. Cambridge Scholars Publishing. p. 225-237.

Reimer PJ, Bard E, Bayliss A, Beck JW, Blackwell PG, Ramsey CB, Buck CE, Cheng H, Edwards RL, Friedrich M, et al. 2013. IntCall3 and Marine13 radiocarbon age calibration curves 0-50,000 years cal BP. Radiocarbon 55(4): 1869-1887.

Ribeiro C. 1884. Les kioekkenmoeddings de la Vallée du Tage. In: Compte Rendu de la IX session du Congrès International d'Anthropologie et d'Archéologie Préhistoriques, Lisbonne 1880.
Lisboa: Typographie de l'Académie des Sciences p. 279-290.

Roche J. 1957. Première datation du Mésolitique portugais par la méthode du Carbone 14. Bol Acad Ciênc Lisb. (29):292-296.

Roche J. 1965. Note sur la stratigraphie de l'amas coquillier mésolithiques de Cabeço de Amoreira (Muge). Comun Serviços Geológicos Port. 48:191-199.

Roche J. 1967. Note sur la stratigraphie de l'amas coquillier mésolithique de Cabeço da Arruda (Muge). Comun Serviços Geológicos Port. LII:79-94.

Roche J. 1972. Le gisement Mésolithique de Moita do Sebastião. Muge, Portugal. Archéologie. Lisboa: Instituto de Alta Cultura.

Roche J, Ferreira OV. 1967. Les fouilles récentes dans les amas coquilliers Mésolithiques de Muge (1952-1965). O Arqueólogo Port. 1:19-41.

Roksandic M. 2006. Analysis of burials from the new excavations of the sites Cabeço da Amoreira and Cabeço da Arruda (Muge, Portugal). In: Bicho N, Carvalho AF, editors. Actas do IV Congresso de Arqueologia Peninsular. Vol. Promontória Monográfica 4. Faro: Universidade do Algarve. p. 1-10.

Roksandic M, Jackes M. 2014. The skeletal assemblage and burial ritual at the site of Cabeço da Amoreira: the 1960s excavations by Veiga Fereira and Roche. In: Roksandic M, Mendonça de Souza S, Eggers S, Burchell M, Klokler D, editors. The cultural dynamics of shell-matrix sites. Albuquerque: University of New Mexico Press. p. 113-129.

Rowley-Conwy P. 2015. The Late Mesolithic of southwest Portugal: a zooarchaeological approach to resource exploitation and settlement patterns. In: Bicho N, Detry C, Price TD, Cunha E, editors. Muge 150th: the 150th anniversary of the discovery of Mesolithic shellmiddens. Vol. 1. Cambridge: Cambridge Scholars Publishing. p. 255-272.

Santos MF, Rolão J, Marques M. 1990. Duas novas jazidas Epipaleolíticas do Baixo Tejo: $\mathrm{n}^{\circ} \mathrm{s} 1$ e 2 do Vale da Fonte da Moça (Almeirim), sua exploração arqueológica e salvaguarda. In: I Congresso do Tejo. Que Tejo, que futuro? Lisboa, 1987. Associação dos Amigos do Tejo. p. 33-38.

van der Schriek T, Passmore D, Stevenson A, Rolão J. 2007. The palaeogeography of Mesolithic settlement-subsistence and shell midden formation in the Muge valley, Lower Tagus Basin, Portugal. The Holocene. 17(3):369-385.

Stuiver M, Pearson GW, Braziunas T. 1986. Radiocarbon age calibration of marine samples back to 9000 cal yr BP. Radiocarbon 28(2B):980-1021.

Taylor RE, Bar-Yosef O. 2014. Radiocarbon dating: an archaeological perspective. 2nd ed. Walnut Creek, CA: Left Coast Press. 
Umbelino C, Cunha E. 2012. The Sado shell middens: anthropological and paleodietary description. In: Gibaja JF, Carvalho AF, Chambon P, editors. Funerary practices in the Iberian Peninsula from the Mesolithic to the Chalcolithic. Oxford: Archaeopress. (BAR International Series). p. 91-102.

Umbelino C, Gonçalves C, Figueiredo O, Pereira T, Cascalheira J, Marreiros J, Évora M, Cunha E, Bicho N. 2015. Life in the Muge Shell Middens: Inferences from the new skeletons recovered from Cabeço da Amoreira. In: Bicho N, Detry C, Price TD, Cunha E, editors. Muge 150th: The 150th Anniversary of the Discovery of Mesolithic Shellmiddens. Vol. I. Newcastle upon Tyne: Cambridge Scholars Publishing. p. 209-223.

Vis G-J, Kasse C, Vandenberghe J. 2008. Late Pleistocene and Holocene palaeogeography of the Lower Tagus Valley (Portugal): effects of relative sea level, valley morphology and sediment supply. Quat Sci Rev. 27(17): 1682-1709.

Zilhão J. 2003. Algumas observações acerca do Mesolítico do interior peninsular e do modelo de passagem ao Neolítico através de colonização pioneira por via marítima. Comentário a A. F. Carvalho. O Arqueólogo Port. 21:108-118. 